Article

\title{
Forecasting Methane Emissions from Hard Coal Mines Including the Methane Drainage Process
}

\author{
Magdalena Tutak ${ }^{1, *(1)}$ and Jarosław Brodny ${ }^{2}$ (I) \\ 1 Faculty of Mining, Safety Engineering and Industrial Automation, Silesian University of Technology, \\ 44-100 Gliwice, Poland \\ 2 Faculty of Organization and Management, Silesian University of Technology, 41-800 Zabrze, Poland; \\ jaroslaw.brodny@polsl.pl \\ * $\quad$ Correspondence: magdalena.tutak@polsl.pl; Tel.: +48-322-372-528
}

Received: 3 September 2019; Accepted: 10 October 2019; Published: 11 October 2019

\begin{abstract}
With regard to underground mining, methane is a gas that, on the one hand, poses a threat to the exploitation process and, on the other hand, creates an opportunity for economic development. As a result of coal exploitation, large amounts of coal enter the natural environment mainly through ventilation systems. Since methane is a greenhouse gas, its emission has a significant impact on global warming. Nevertheless, methane is also a high-energy gas that can be utilized as a very valuable energy resource. These different properties of methane prompted an analysis of both the current and the future states of methane emissions from coal seams, taking into account the possibilities of its use. For this reason, the following article presents the results of the study of methane emissions from Polish hard coal mines between 1993-2018 and their forecast until 2025. In order to predict methane emissions, research methodology was developed based on artificial neural networks and selected statistical methods. The multi-layer perceptron (MLP) network was used to make a prognostic model. The aim of the study was to develop a method to predict methane emissions and determine trends in terms of the amount of methane that may enter the natural environment in the coming years and the amount that can be used as a result of the methane drainage process. The methodology developed with the use of neural networks, the conducted research, and the findings constitute a new approach in the scope of both analysis and prediction of methane emissions from hard coal mines. The results obtained confirm that this methodology works well in mining practice and can also be successfully used in other industries to forecast greenhouse gas and other substance emissions.
\end{abstract}

Keywords: underground coal mine; methane emissions forecast; methane drainage; greenhouse gas; coal mine methane

\section{Introduction}

Methane is emitted from a range of natural and anthropogenic sources. The main anthropogenic sources of methane emissions worldwide include coal mining, agriculture, waste, biomass, and the incomplete combustion of fossil fuels or natural gas distribution [1].

In Poland, nearly $29 \%$ of total methane emissions into the atmosphere are related to the direct hard coal mining process. They include ventilation emissions and emissions from methane drainage systems. Hard coal mining in Poland is the second main source of methane emissions into the atmosphere, just behind agriculture (about 34\% of total methane emissions into the atmosphere in Poland) [2].

Since methane is one of the most harmful greenhouse gases, such a large share of mining industry in its emissions is a serious problem for this industry. In addition, due to its flammable and explosive properties, methane also poses a significant threat to the safety of mining processes [3,4]. The occurrence of either fire or explosion of methane in underground mining excavations is associated with huge 
material losses and great perils to the life and the health of the crew. The flammability and the explosiveness of methane are due to its high energy potential, which is increasingly being used in the energy sector. The process of methane extraction from coal deposits reduces its emission into the atmosphere and the risk of explosion or fire, and it allows additional economic benefits for mining enterprises [5]. That is why the ongoing development of the methane drainage process is being observed, which is an opportunity for these enterprises to diversify their production and to make effective use of this gas.

Methane is a gas accompanying the hard coal seams. Once emitted into the atmosphere, it can survive for nine to 15 years (average perturbation life 12.4). Given the amount of greenhouse gas emissions, methane ranks second behind carbon dioxide [6,7]. Methane is a powerful greenhouse gas with a global warming potential (GWP) 34 times greater than carbon dioxide over a 100 year time period and 86 times greater than carbon dioxide over a 20 year time period according to the Intergovernmental Panel on Climate Change [8].

This gas is classified as both flammable and explosive due to the possibility of rapid ignition in the atmosphere with a minimum concentration of $12 \%$ oxygen, which may result in local fires and explosions [9].

On the other hand, out of all fossil energy resources, methane is the cleanest source of energy [10]. To be more precise, it has the lowest carbon dioxide $\left(\mathrm{CO}_{2}\right)$ emission factor (almost two times lower when compared to coal) [11,12].

Methane emissions are inextricably linked to hard coal exploitation processes. Therefore, this article focuses on the analysis of methane emissions reported in the hard coal production process. All methane released during and after mining operations is called coal mine methane. The main sources (associated with coal exploitation processes) from which it enters the atmosphere are as follows $[13,14]$ :

- Degasification systems at underground coal mines (also commonly referred to as drainage systems);

- Ventilation air from underground mines, which contains dilute concentrations of methane;

- Abandoned or closed mines, from which methane may seep out through vent holes or through fissures or cracks in the ground;

- Fugitive emissions from post-mining operations, in which coal continues to emit methane as it is stored in piles and transported.

In Poland, the main source of methane emissions is mined coal, the pores of which contain this gas. The mining process opens those pores from which methane enters the mine atmosphere. Then, through the ventilation system, it is emitted into mining excavations to later reach the natural environment. The unused part of methane extracted in the methane drainage process also leaks into the atmosphere. This situation is particularly unfavorable and incomprehensible, as this system is quite expensive and methane itself is considered a very good energy fuel $[15,16]$.

Despite the undoubted benefits of the methane capture process used in mines, related activities are not yet very common in Polish mines.

In 2018, the total methane emissions reported for the Polish hard coal mines amounted to 919.1 million $\mathrm{m}^{3} \mathrm{CH}_{4}$, of which only 317 million $\mathrm{m}^{3} \mathrm{CH}_{4}$ (34.6\%) was covered by methane drainage systems. Unfortunately, this gas was not used entirely for economic purposes, since as high as 113.9 million $\mathrm{m}^{3}$ was emitted into the atmosphere. In other words, over $30 \%$ of gas was not utilized whatsoever. The use of methane for economic purposes was only $22.2 \%$ in 2018 when compared to the total methane emissions. This means that almost $80 \%$ of methane from hard coal was emitted into the atmosphere [17].

This results in a significant deterioration of the atmosphere and a waste of valuable energy raw material. In addition, capturing only about $30 \%$ of methane released in the exploitation process also causes a high risk of its ignition and explosion in mining excavations. The methane-related hazard is one of the most dangerous risks in underground coal mining. The significance of this problem is also 
evidenced by the fact that methane is present in virtually all coal mines, and its amount in the exploited seams was reported to have significantly increased in recent years due to their deeper location.

It should also be noted that, in the last twenty years, the number of mines in Poland has significantly decreased. The mass (expressed in millions of tons) of mined coal has also decreased (Figure 1) [17]. Despite this, the amount of methane released during mining is on the rise. This is the result of the exploitation of coal seams with high and increasing absolute methane content [volumetric amount of methane released into excavations (the so-called methane content in ventilation air) and captured by methane drainage systems per unit of time]. As a consequence, despite the decline in hard coal exploitation in Polish mines, the methane threat is increasing.

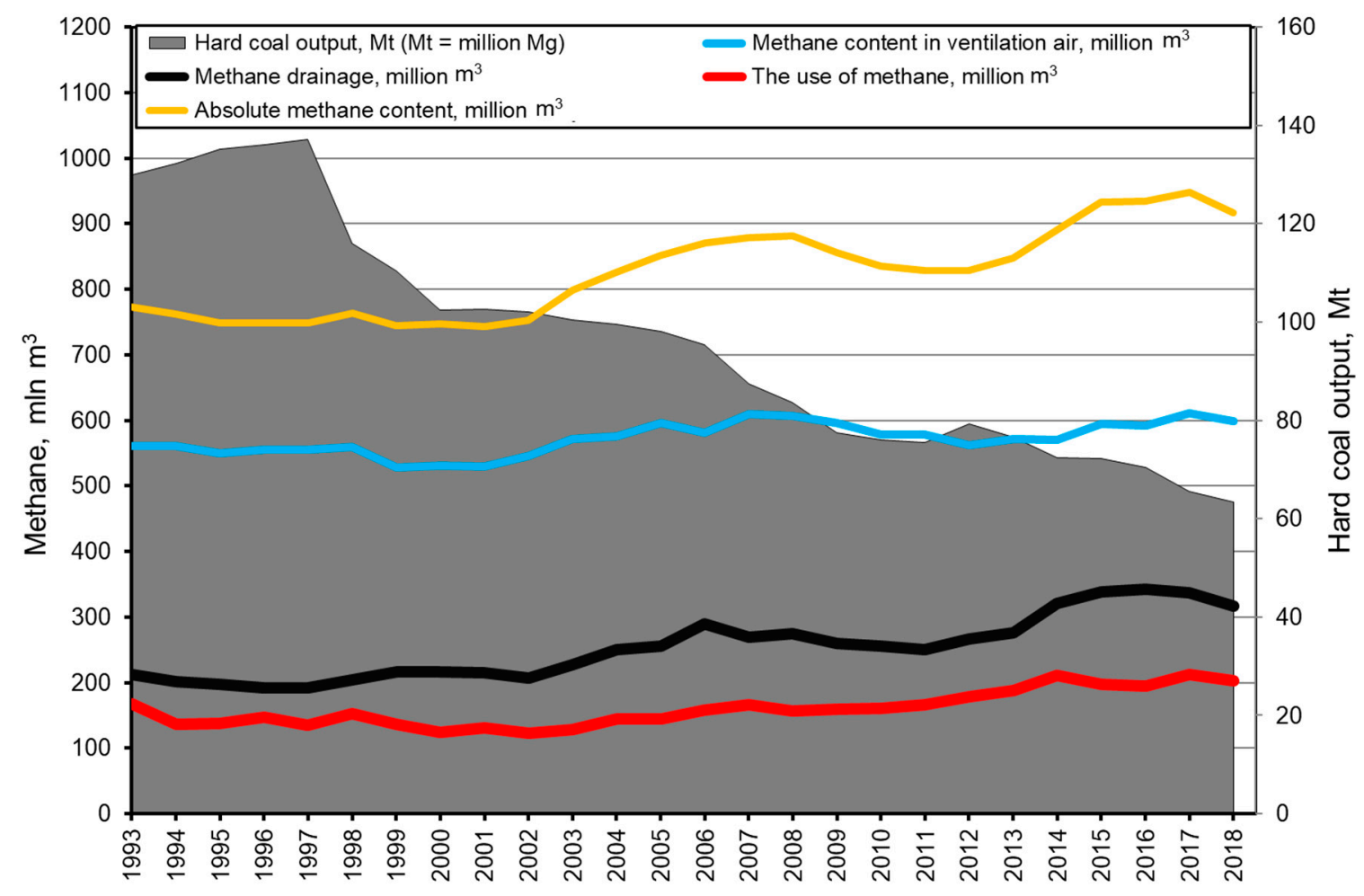

Figure 1. The amount of methane released and captured by the methane drainage system in Polish hard coal mines (own study based on [17]).

The amount of methane released from coal seams is also due to a high concentration of coal output, which is done by increasing longwall lengths and mining speed. This combined with a large depth of exploitation and the increasing saturation of coal seams with methane causes its elevated emissions. The average annual increase in the depth of exploitation in Polish hard coal mines is about $8 \mathrm{~m} /$ year $[18,19]$. In addition, at great depths, dynamic release of free methane occurs, leading to adverse effects. Here, methane is trapped in tectonic disturbance zones (faults, crevices) under high hydrostatic pressure of overlaying rocks. These phenomena also lead to a significant increase in methane emissions.

In 2018, the total methane emissions of Polish hard coal mines amounted to 916.1 million $\mathrm{m}^{3} \mathrm{CH}_{4}$. When considering the amount of coal extracted this year (63.4 million tons), one ton of coal emitted $14.45 \mathrm{~m}^{3} \mathrm{CH}_{4}$. For comparison, in 1994, one ton of extracted coal resulted in the emission of $5.76 \mathrm{~m}^{3}$ $\mathrm{CH}_{4}$ (with extraction of 132.7 million tons/year and 69 active hard coal mines) [17]. These figures show how significantly the amount of methane per ton of extracted coal changed. It also indicates the importance of the problem that the Polish mining industry needs to face in the coming years. Moreover, it should be noted that the Polish economy depends to a large extent on energy obtained from coal combustion. Therefore, it is impossible to either cease or significantly reduce exploitation 
in the near future, despite the increasing pressure from the European Union and other organizations concerned with environmental protection. Undoubtedly, both the process of coal exploitation and its combustion are not environmentally friendly, yet for the time being, the Polish economy is not prepared for rapid changes in terms of transition to other, more ecological energy sources [20]. That is why, at the current stage of economic development, it seems reasonable to develop more efficient methods of coal exploitation and usage, which would also reduce harmful emissions into the atmosphere.

In this regard, it seems appropriate to carry out an analysis in terms of predicted amounts of methane that will be emitted by coal mining in the coming years.

Forecasts for methane release usually include mining excavations in terms of exploitation safety. This type of forecast can be exemplified by the dynamic prediction of absolute methane content of bearing capacity of longwalls [18], the prediction of methane concentration distribution in mining excavations using the Computational Fluid Dynamics (CFD) methods [21,22], or the prediction of methane concentration using artificial neural networks [23,24]. This approach is justified when considering safety of the exploitation process. As already mentioned, methane is considered an immensely hazardous gas.

Nevertheless, from the point of view of sustainable development of the country, other elements are also of key importance. They include the effects methane has on the natural environment and the provision of an additional-in this case, ecological—energy raw material, which methane undoubtedly is. The so-called sustainable economy model, which is becoming effective in the European Union, enforces ecological, socially acceptable, and economically effective measures in this respect.

The exploitation of methane coexisting with coal can be an important factor when improving the economic condition of mining enterprises. With regard to the decarbonization policy strongly supported by the European Union [25,26], effective methane extraction can be crucial for improving the image of coal mining. This process enhances exploitation safety, reduces the negative impact on the environment, and can improve the economic condition of these enterprises.

In this context, knowledge of the future amounts of methane emissions, including its acquisition, may become the basis for making strategic decisions in the field of energy management both in the country and by mining enterprises.

Little research is devoted to the issue of predicting methane emissions from Polish mines. The problem of methane emissions in the atmosphere was studied by [27]. Here, the authors focused on the prediction of methane emissions from a closed mine. In a study by [28], the concept of predicting the amount of methane emitted from closed mines was presented. In study [29], Kirchgessner et al. presented an equation based on the multi-linear regression technique between coalbed methane contents, coal productions, and mine emissions (with $R^{2}=0.59$ ). The form of the equation that they developed is a standard multi-linear function with a slope and intercept.

Thus far, no method has been developed to predict the amount of methane (ventilation methane emissions) released to the atmosphere from active mines or the amount of methane captured by methane drainage systems and emitted from these systems into the atmosphere when considering historical data or the emission trend.

Therefore, this paper presents a method for predicting the amount of methane (ventilation methane emissions) emitted into the atmosphere by Polish mines and captured by methane drainage systems. This method enabled the analysis that allowed for the forecast of methane emissions from these mines until 2025. Moreover, this forecast also takes into account the amount of methane captured by methane drainage systems and the amount emitted into the natural environment. The analysis was carried out based on the data on methane emissions from Polish coal mines between 1993 and 2018.

In order to predict gas emissions, statistical methods are most commonly used, including Autoregressive Integrated Moving Average (ARIMA) models for the time series analysis $[30,31]$ and regression analysis [32]. However, for the selected parameters related to methane emissions in the mining production process, the authors decided to use artificial neural networks. The existing literature 
failed to apply these networks to predict methane emissions into the atmosphere, especially from hard coal mines.

Despite the small number of studies covering the use of intelligent methods to predict emission phenomena, methods based on artificial intelligence should be utilized to a greater extent for this purpose.

The study discuses both the subject area and the developed research methodology. The analysis involved five parameters typical of methane emissions (coal output, total methane emissions, ventilation methane emissions, the amount of methane captured by methane drainage systems, and the amount of methane used) in individual years. Then, the parameters were referred to one ton of extracted coal. Correlations between these parameters were also determined for the analyzed period. Afterwards, a tool developed for and used in the analysis based on the artificial neural network model was discussed. The paper also presents the forecast results together with an error analysis and conclusions. Selected statistical methods were also used to analyze both the data and the findings.

\section{Materials and Methods}

\subsection{Study Area}

The main area where hard coal and coking mines are located and which emits the highest amount of methane in Poland is the area of the Upper Silesian Coal Basin (Figure 2). In these mines, methane is treated as a raw material accompanying hard coal deposits, which since 1962 has been subject to documentation principles specified in geological and mining law [33]. Since the 1990s, methane has also been treated as the useful gas [33].

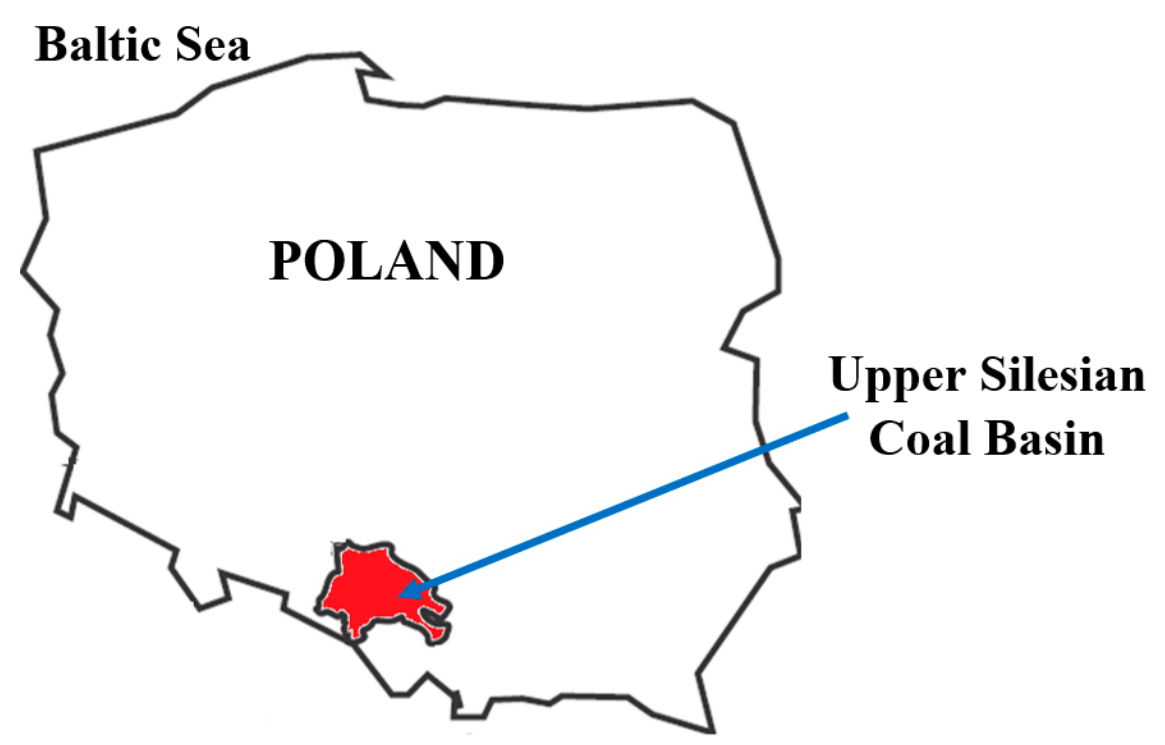

Figure 2. Location of the Upper Silesian Coal Basin in Poland.

The supposed economic resources of methane in the Upper Silesian Coal Basin were set at a level of 168.1 billion $\mathrm{m}^{3}$ (with a total resource potential of around 230-250 billion $\mathrm{m}^{3}$ ). The prognostic resources amounted to 54.2 billion $\mathrm{m}^{3}$ and the prospective resources to 52.8 billion $\mathrm{m}^{3}$. The remaining parts of these resources were documented as the main or the accompanied mineral. The maximum depth to determine methane resources was set at $1500 \mathrm{~m}$ [34].

The model distributions of methane content in hard coal seams in the Upper Silesian Coal Basin are shown in Figure 3, depending on the depth. Coal mines in the Upper Silesian Coal Basin are in the northern range in terms of methane content in hard coal seams. 


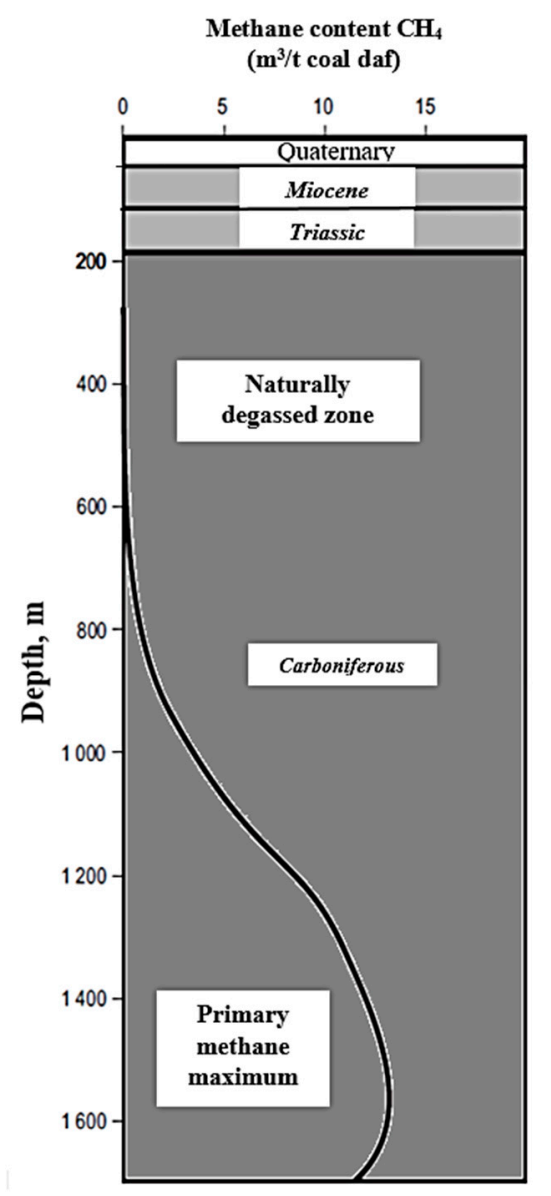

(a)

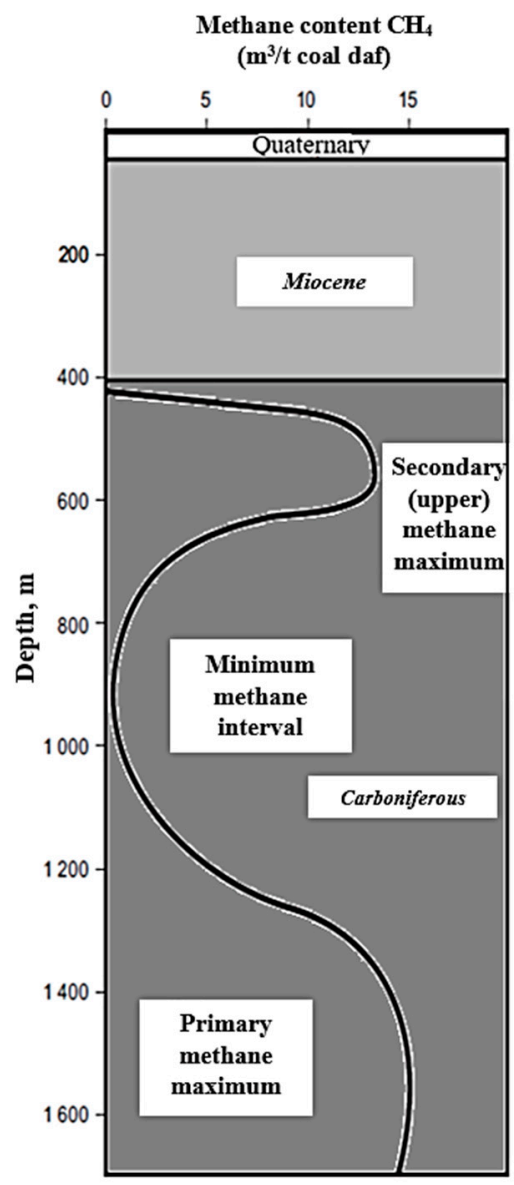

(b)

Figure 3. The model distributions of methane content in hard coal seams in the northern parts of Upper Silesian Coal Basin (a) and the southern parts of Upper Silesian Coal Basin (b) (own study based on [35]).

These models clearly show that the greatest methane emissions are found in seams located at a depth of less than $1000 \mathrm{~m}$. Currently, the vast majority of exploited seams are located at these depths [35].

\subsection{Data}

Data from the State Mining Authority [17] and the Annual Report on the state of basic natural and technical hazards in hard coal mining [36] were used to analyze the current state of methane emissions, methane drainage, and methane emissions from methane drainage systems into the atmosphere, as well as to make predictions. Data on the amount of methane emitted from hard coal mines in Poland into the atmosphere (including methane drainage systems) come from measurements conducted by ventilation services of hard coal mines. They are required to both register and pass this information to the State Mining Authority. In order to determine ventilation methane content, a complex measurement procedure needs to be be carried out in each mine. It is based on continuous measurements of the speed of the air stream flowing through mining excavations, methane air concentrations, and the geometry of excavations. Measurements are carried out using stationary air flow velocity and methane concentration meters, which are built-in in mining excavations. In turn, the total methane content is determined by adding up the amount of methane captured by methane drainage systems and the 
amount of ventilation methane. An advanced ventilation parameter registration system (in most cases automatic) supervised by specialized ventilation services guarantees the reliability of data.

Data on both the extraction and the emission of methane from Polish hard coal mines for the years 1993-2018 are presented in Table 1. The volume of extraction is specified in megatons ( $\mathrm{Mt}=$ million $\mathrm{Mg}$; $\mathrm{mln}=$ million), while the total methane and ventilation content, methane drainage, and methane usage are in millions of $\mathrm{m}^{3}$.

Table 1. Methane extraction and emission from Polish hard coal mines between 1993-2018.

\begin{tabular}{|c|c|c|c|c|c|c|}
\hline Year & $\begin{array}{c}\text { Hard Coal } \\
\text { Output, } \\
\text { Mt }\end{array}$ & $\begin{array}{c}\text { Absolute } \\
\text { Methane } \\
\text { Content, } \\
\text { million } \text { m }^{3}\end{array}$ & $\begin{array}{l}\text { Methane Content } \\
\text { in Ventilation Air, } \\
\text { million } \mathrm{m}^{3}\end{array}$ & $\begin{array}{l}\text { Methane } \\
\text { Drainage, } \\
\text { million } \mathrm{m}^{3}\end{array}$ & $\begin{array}{l}\text { The Use of } \\
\text { Methane, } \\
\text { million } \mathrm{m}^{3}\end{array}$ & $\begin{array}{c}\text { Methane } \\
\text { Emissions from } \\
\text { Drainage Systems, } \\
\text { million } \mathrm{m}^{3}\end{array}$ \\
\hline 1993 & 130.0 & 773.3 & 560.5 & 212.8 & 167.6 & 45.2 \\
\hline 1994 & 132.3 & 762.0 & 560.8 & 201.2 & 136.3 & 64.9 \\
\hline 1995 & 135.2 & 748.0 & 550.5 & 197.5 & 137.1 & 60.4 \\
\hline 1996 & 136.0 & 748.4 & 555.9 & 192.5 & 147.5 & 45 \\
\hline 1997 & 137.1 & 748.4 & 555.9 & 192.5 & 134.4 & 58.1 \\
\hline 1998 & 115.9 & 763.3 & 559.7 & 203.6 & 152.7 & 50.9 \\
\hline 1999 & 110.4 & 744.5 & 528.4 & 216.1 & 136.9 & 79.2 \\
\hline 2000 & 102.5 & 746.9 & 530.8 & 216.1 & 124.0 & 92.1 \\
\hline 2001 & 102.6 & 743.7 & 529.4 & 214.3 & 131.5 & 82.8 \\
\hline 2002 & 102.1 & 752.6 & 545.3 & 207.3 & 122.4 & 84.9 \\
\hline 2003 & 100.4 & 798.1 & 571.0 & 227.1 & 127.8 & 99.3 \\
\hline 2004 & 99.5 & 825.9 & 575.0 & 250.9 & 144.5 & 106.4 \\
\hline 2005 & 98.1 & 851.1 & 595.8 & 255.3 & 144.8 & 110.5 \\
\hline 2006 & 95.4 & 870.3 & 580.8 & 289.5 & 158.3 & 131.2 \\
\hline 2007 & 87.4 & 878.9 & 610.1 & 268.8 & 165.7 & 103.1 \\
\hline 2008 & 83.6 & 880.9 & 606.7 & 274.2 & 156.5 & 117.7 \\
\hline 2009 & 77.4 & 855.7 & 595.9 & 259.8 & 159.5 & 100.3 \\
\hline 2010 & 76.1 & 834.9 & 579.0 & 255.9 & 161.1 & 94.8 \\
\hline 2011 & 75.5 & 828.8 & 578.6 & 250.2 & 166.3 & 83.9 \\
\hline 2012 & 79.2 & 828.2 & 561.5 & 266.7 & 178.6 & 88.1 \\
\hline 2013 & 76.5 & 847.8 & 571.2 & 276.6 & 187.7 & 88.9 \\
\hline 2014 & 72.5 & 891.2 & 570.1 & 321.1 & 211.4 & 109.7 \\
\hline 2015 & 72.2 & 933.0 & 594.0 & 339 & 197.1 & 141.9 \\
\hline 2016 & 70.4 & 933.8 & 591.7 & 342.1 & 195.0 & 147.1 \\
\hline 2017 & 65.5 & 948.5 & 611.5 & 337.0 & 212.0 & 125 \\
\hline 2018 & 63.4 & 916.1 & 599.1 & 317.0 & 203.1 & 113.9 \\
\hline Sum & 2497.2 & 21454.3 & $14,869.2$ & 6585.1 & 4159.8 & 2425.3 \\
\hline Average & 96.05 & 825.17 & 571.89 & 253.27 & 159.99 & 93.28 \\
\hline $\begin{array}{l}\text { Standard } \\
\text { deviation }\end{array}$ & 23.56 & 67.84 & 24.31 & 48.20 & 27.26 & 28.09 \\
\hline
\end{tabular}

Based on the data contained in Table 1, the total and the ventilation methane emissions as well as the amount of methane drainage and the economic use of methane per one ton of extracted coal were determined.

A statistical analysis was performed for the data presented in Tables 1 and 2. It was based on the Pearson correlation coefficients between the studied variables and the correlation matrix between these coefficients. The results are summarized in Tables 3 and 4, respectively.

The Pearson correlation coefficients were calculated from the relationship:

$$
r_{X Y}=\frac{\operatorname{cov}(X, Y)}{\sigma_{x} \sigma_{Y}}=\frac{\left(\sum_{i=1}^{n} \sum_{j=1}^{m} P\left(X=x_{i}, Y=y_{i}\right) x_{i} y_{j}\right)-\bar{X} \bar{Y}}{\sqrt{\left(\sum_{i=1}^{n} P\left(X=x_{i}\right) x_{i}^{2}\right)-\overline{X^{2}} \sqrt{\left(\sum_{i=1}^{m} P\left(Y=y_{i}\right) y_{i}^{2}\right)-\overline{Y^{2}}}}}
$$


Table 2. Total methane emissions, ventilation methane emissions, amount of methane drainage, use of methane, and methane emissions from drainage systems per one ton of extracted coal.

\begin{tabular}{|c|c|c|c|c|c|}
\hline Year & $\begin{array}{l}\text { Absolute } \\
\text { Methane } \\
\text { Content per } \\
\text { One Ton, } \mathrm{m}^{3}\end{array}$ & $\begin{array}{l}\text { Methane Content } \\
\text { in Ventilation Air } \\
\text { per One Ton, } \mathrm{m}^{3}\end{array}$ & $\begin{array}{l}\text { Methane } \\
\text { Drainage per } \\
\text { One Ton, } \mathrm{m}^{3}\end{array}$ & $\begin{array}{l}\text { The Use of } \\
\text { Methane per } \\
\text { One Ton, } \\
\text { million } \mathrm{m}^{3}\end{array}$ & $\begin{array}{c}\text { Methane Emissions } \\
\text { from Drainage } \\
\text { Systems per One Ton, } \\
\text { m }^{3}\end{array}$ \\
\hline 1993 & 5.95 & 4.31 & 1.64 & 1.29 & 0.35 \\
\hline 1994 & 5.76 & 4.24 & 1.52 & 1.03 & 0.49 \\
\hline 1995 & 5.53 & 4.07 & 1.46 & 1.01 & 0.45 \\
\hline 1996 & 5.50 & 4.09 & 1.42 & 1.08 & 0.33 \\
\hline 1997 & 5.46 & 4.05 & 1.40 & 0.98 & 0.42 \\
\hline 1998 & 6.59 & 4.83 & 1.76 & 1.32 & 0.44 \\
\hline 1999 & 6.74 & 4.79 & 1.96 & 1.24 & 0.72 \\
\hline 2000 & 7.29 & 5.18 & 2.11 & 1.21 & 0.90 \\
\hline 2001 & 7.25 & 5.16 & 2.09 & 1.28 & 0.81 \\
\hline 2002 & 7.37 & 5.34 & 2.03 & 1.20 & 0.83 \\
\hline 2003 & 7.95 & 5.69 & 2.26 & 1.27 & 0.99 \\
\hline 2004 & 8.30 & 5.78 & 2.52 & 1.45 & 1.07 \\
\hline 2005 & 8.68 & 6.07 & 2.60 & 1.48 & 1.13 \\
\hline 2006 & 9.12 & 6.09 & 3.03 & 1.66 & 1.38 \\
\hline 2007 & 10.06 & 6.98 & 3.08 & 1.90 & 1.18 \\
\hline 2008 & 10.54 & 7.26 & 3.28 & 1.87 & 1.41 \\
\hline 2009 & 11.06 & 7.70 & 3.36 & 2.06 & 1.30 \\
\hline 2010 & 10.97 & 7.61 & 3.36 & 2.12 & 1.25 \\
\hline 2011 & 10.98 & 7.66 & 3.31 & 2.20 & 1.11 \\
\hline 2012 & 10.46 & 7.09 & 3.37 & 2.26 & 1.11 \\
\hline 2013 & 11.08 & 7.47 & 3.62 & 2.45 & 1.16 \\
\hline 2014 & 12.29 & 7.86 & 4.43 & 2.92 & 1.51 \\
\hline 2015 & 12.92 & 8.23 & 4.70 & 2.73 & 1.97 \\
\hline 2016 & 13.26 & 8.40 & 4.86 & 2.77 & 2.09 \\
\hline 2017 & 14.48 & 9.34 & 5.15 & 3.24 & 1.91 \\
\hline 2018 & 14.45 & 9.45 & 5.00 & 3.20 & 1.80 \\
\hline Sum & 240.03 & 164.73 & 75.30 & 47.22 & 28.08 \\
\hline Average & 9.23 & 6.34 & 2.90 & 1.82 & 1.08 \\
\hline $\begin{array}{l}\text { Standard } \\
\text { deviation }\end{array}$ & 2.85 & 1.68 & 1.19 & 0.71 & 0.51 \\
\hline
\end{tabular}

Table 3. The matrix of the correlation coefficients between the variables under analysis for the methane extraction and emission from Polish hard coal mines between 1993-2018.

\begin{tabular}{ccccccc}
\hline Variable & $\begin{array}{c}\text { Hard Coal } \\
\text { Output }\end{array}$ & $\begin{array}{c}\text { Absolute } \\
\text { Methane } \\
\text { Content }\end{array}$ & $\begin{array}{c}\text { Methane } \\
\text { Content in } \\
\text { Ventilation Air }\end{array}$ & $\begin{array}{c}\text { Methane } \\
\text { Drainage }\end{array}$ & $\begin{array}{c}\text { The Use of } \\
\text { Methane }\end{array}$ & $\begin{array}{c}\text { Emissions from } \\
\text { Drainage } \\
\text { Systems }\end{array}$ \\
\hline Hard coal output & 1.0000 & -0.8354 & -0.6171 & -0.8645 & -0.7090 & -0.7955 \\
\hline Absolute methane content & -0.8354 & 1.0000 & 0.8700 & 0.9686 & 0.8372 & 0.6179 \\
\hline $\begin{array}{c}\text { Methane content in } \\
\text { ventilation air }\end{array}$ & -0.6171 & 0.8700 & 1.0000 & 0.7202 & 0.6362 \\
\hline Methane drainage & -0.8645 & 0.9686 & 0.7202 & 1.0000 & 0.8667 & 0.8750 \\
\hline The use of methane & -0.7090 & 0.8372 & 0.6179 & 0.8667 & 0.0000 & 0.5168 \\
\hline $\begin{array}{c}\text { Methane emissions from } \\
\text { drainage systems }\end{array}$ & -0.7955 & 0.8497 & 0.6362 & 0.8750 & 0.5168 \\
\hline
\end{tabular}


Table 4. The matrix of the correlation coefficients between the variables under analysis for the methane extraction and emission from Polish hard coal mines between 1993-2018 per one ton.

\begin{tabular}{cccccc}
\hline Variable & $\begin{array}{c}\text { Absolute } \\
\text { Methane } \\
\text { Content }\end{array}$ & $\begin{array}{c}\text { Methane } \\
\text { Content in } \\
\text { Ventilation Air }\end{array}$ & $\begin{array}{c}\text { Methane } \\
\text { Drainage }\end{array}$ & $\begin{array}{c}\text { The Use of } \\
\text { Methane }\end{array}$ & $\begin{array}{c}\text { Methane } \\
\text { Emissions from } \\
\text { Drainage Systems }\end{array}$ \\
\hline Absolute methane content & 1.0000 & 0.9955 & 0.9909 & 0.9730 & 0.9462 \\
\hline $\begin{array}{c}\text { Methane content in } \\
\text { ventilation air }\end{array}$ & 0.9955 & 1.0000 & 0.9736 & 0.9578 & 0.9271 \\
\hline Methane drainage & 0.9909 & 0.9736 & 1.0000 & 0.9792 & 0.9587 \\
\hline The use of methane & 0.9730 & 0.9578 & 0.9792 & 1.0000 & 0.8810 \\
\hline $\begin{array}{c}\text { Methane emissions from } \\
\text { drainage systems }\end{array}$ & 0.9462 & 0.9271 & 0.9587 & 0.8810 & 1.0000 \\
\hline
\end{tabular}

The correlation analysis between the variables was carried out for the level of statistical significance at $p<0.05$. The analysis of the results showed that the studied variables were characterized by different values of the correlation coefficient (Tables 3 and 4 ).

For the variables presented in Table 1, the highest value of this coefficient occurred between total methane emissions and methane drainage (0.9686), methane drainage and methane emissions from methane drainage (0.8749), methane drainage and methane utilization (0.8666), and between total and ventilation methane emissions (0.8700).

For the variables presented in Table 2, high values of the correlation coefficient (over 0.9) occurred for all studied variables except for methane drainage per ton of coal and emissions into the atmosphere from methane drainage systems per ton of coal. For these variables, the correlation coefficient value was 0.8810 .

Graphic relationships along with the parameters selected for the statistical analysis between the studied variables are shown in Figures 4-7 for the data presented in Table 1 and in Figures 8-11 for the data presented in Table 2.
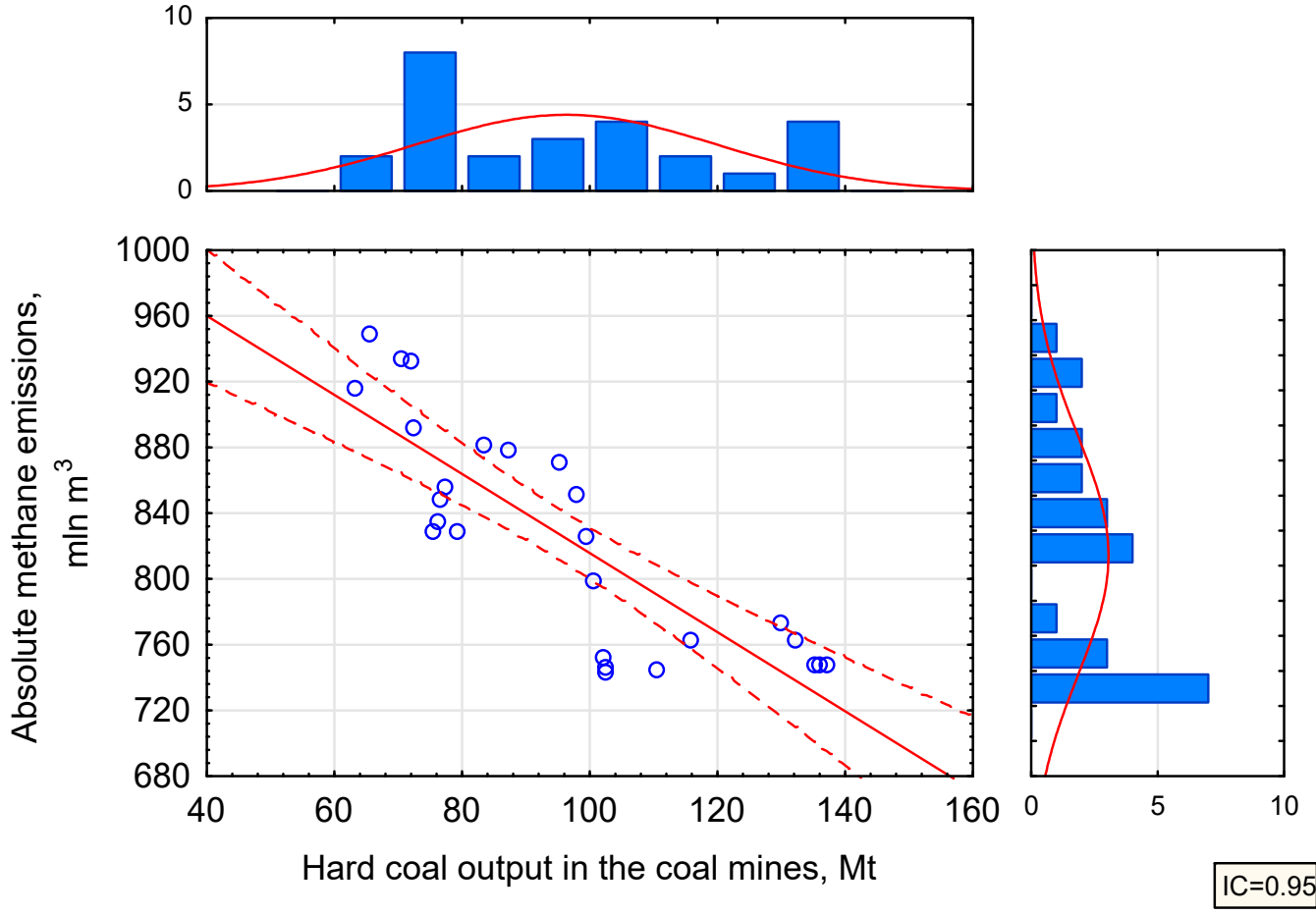

Figure 4. Relationship between hard coal output and absolute methane emissions in hard coal mines in Poland. 

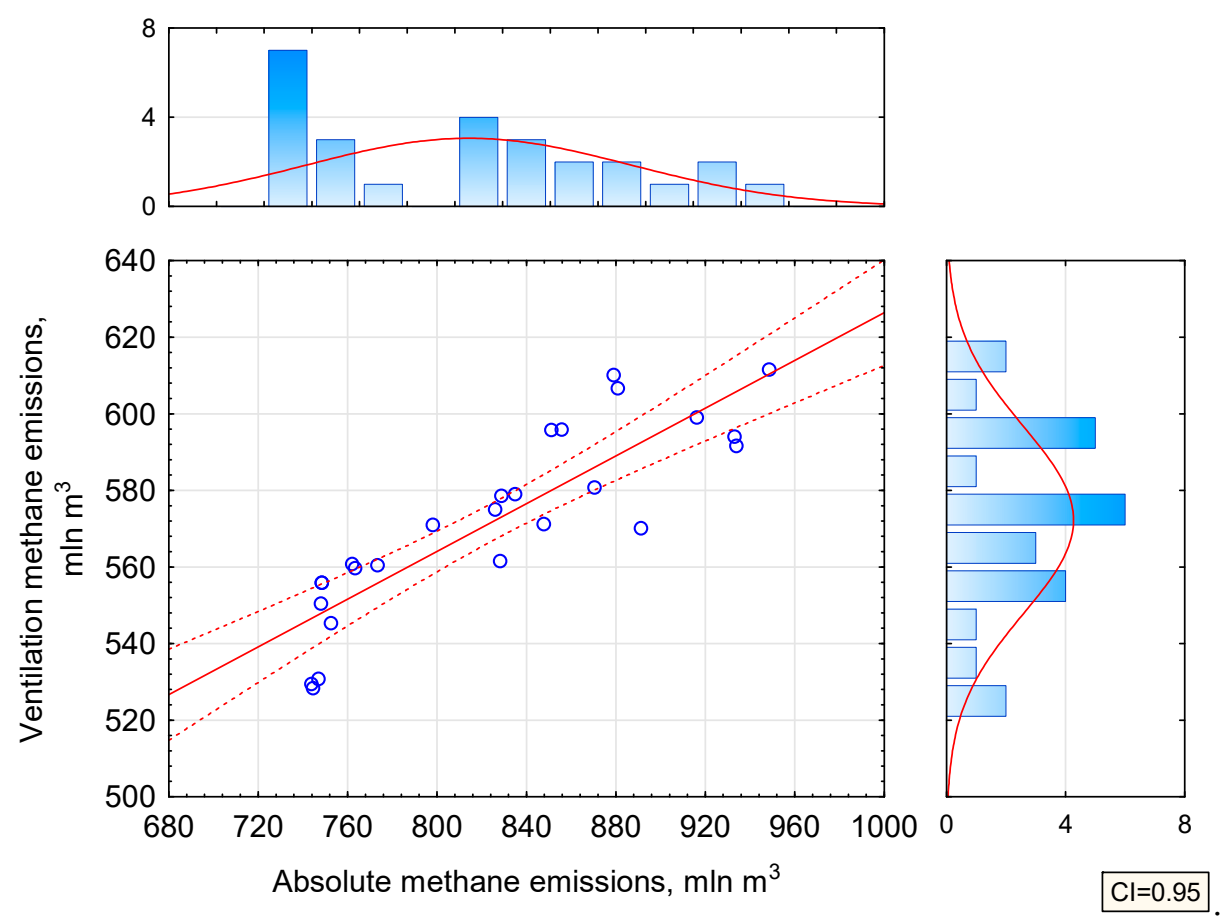

Figure 5. Relationship between absolute methane emissions and ventilation methane emissions in hard coal mines in Poland.
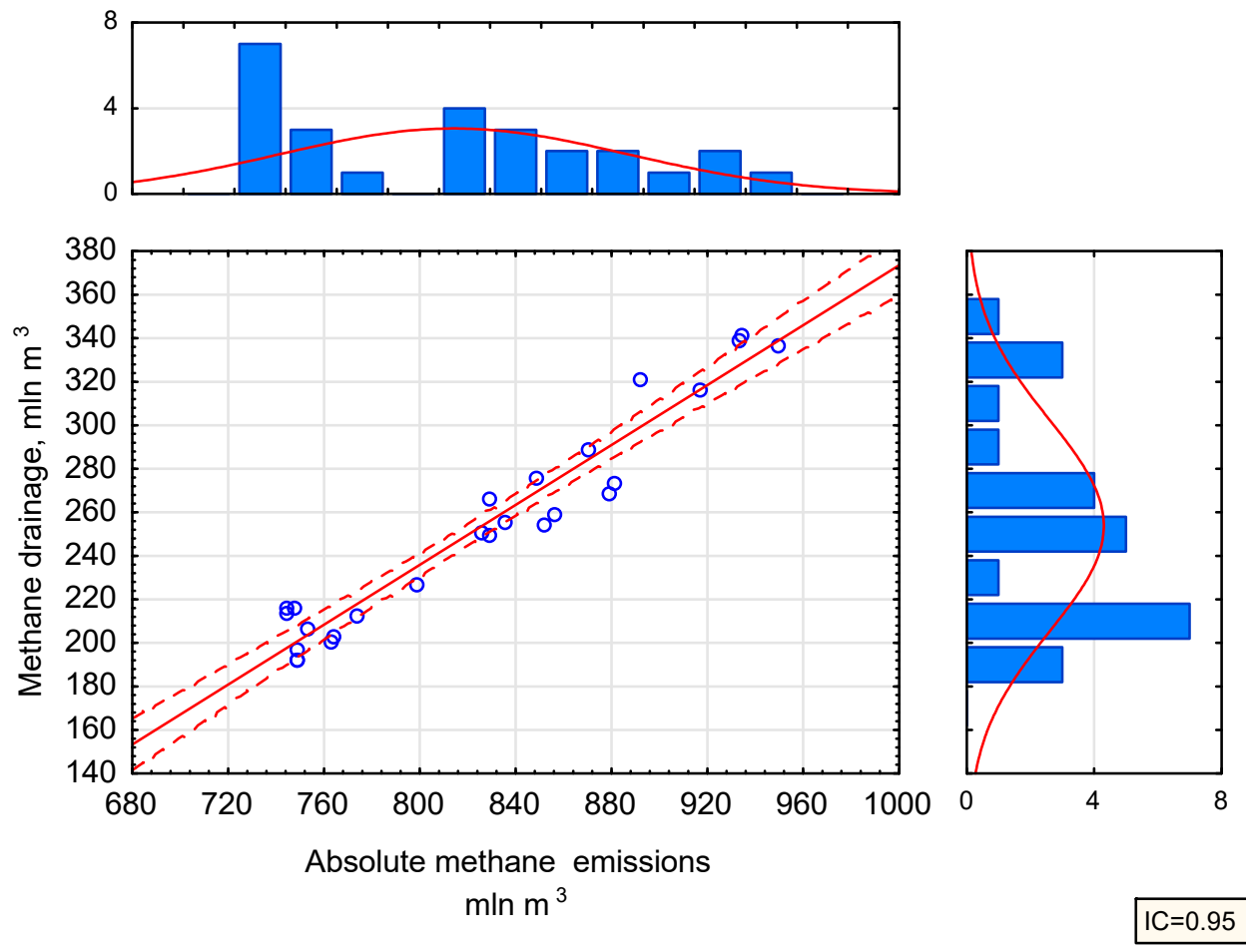

Figure 6. Relationship between absolute methane emissions and methane drainage in hard coal mines in Poland. 

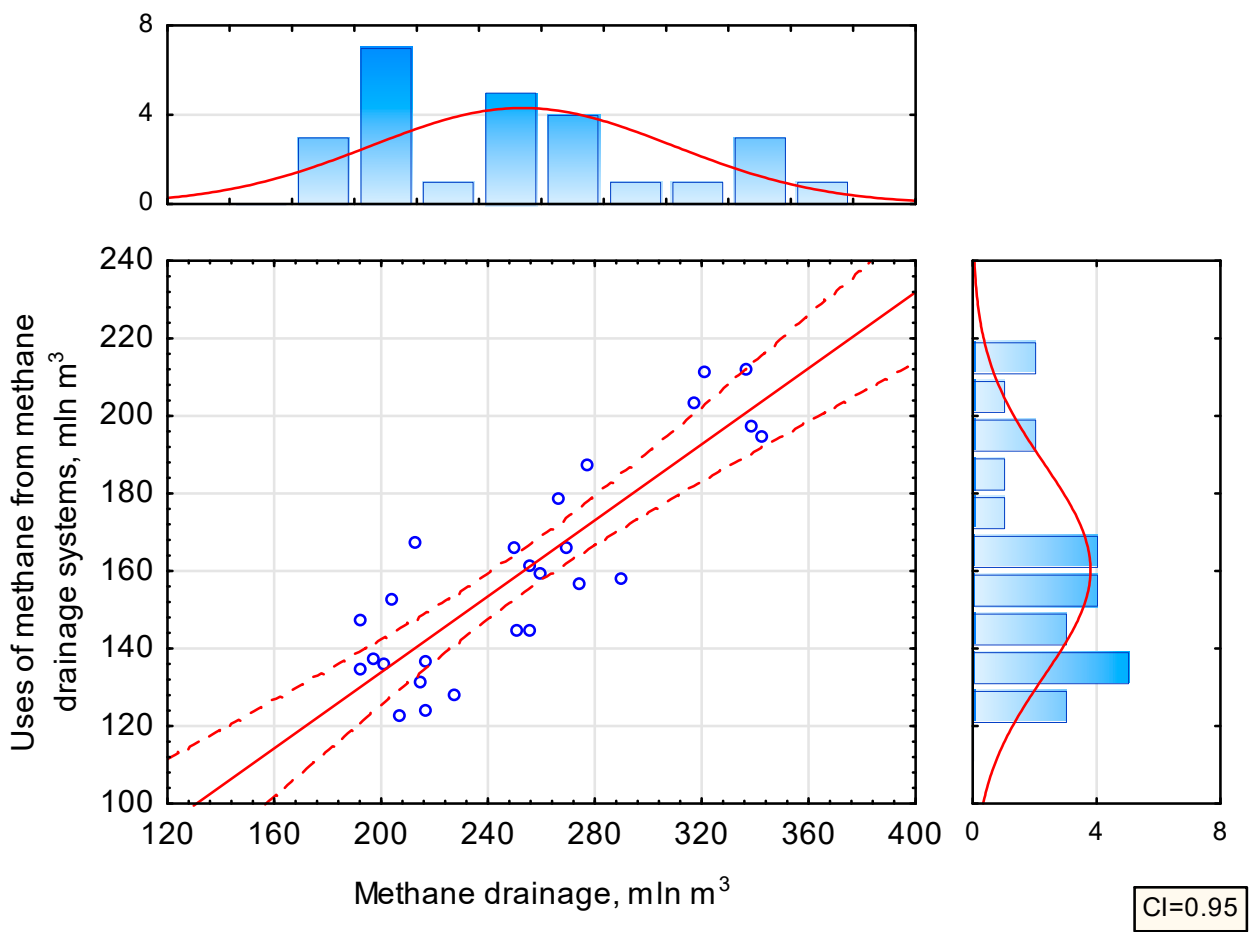

Figure 7. Relationship between methane drainage and uses of methane from methane drainage system in Poland.
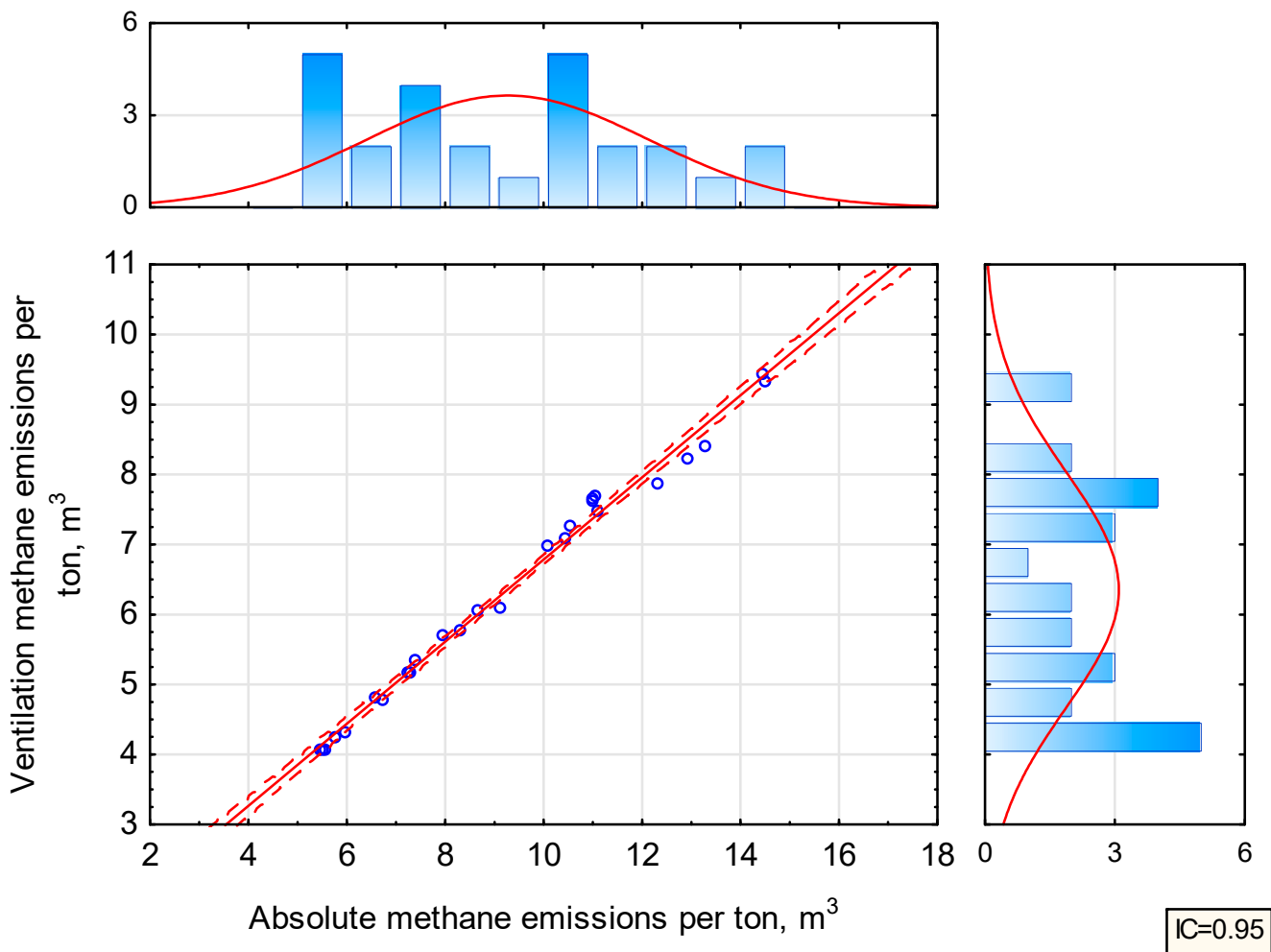

Figure 8. Relationship between absolute methane emissions and ventilation methane emissions per one ton in hard coal mines in Poland. 

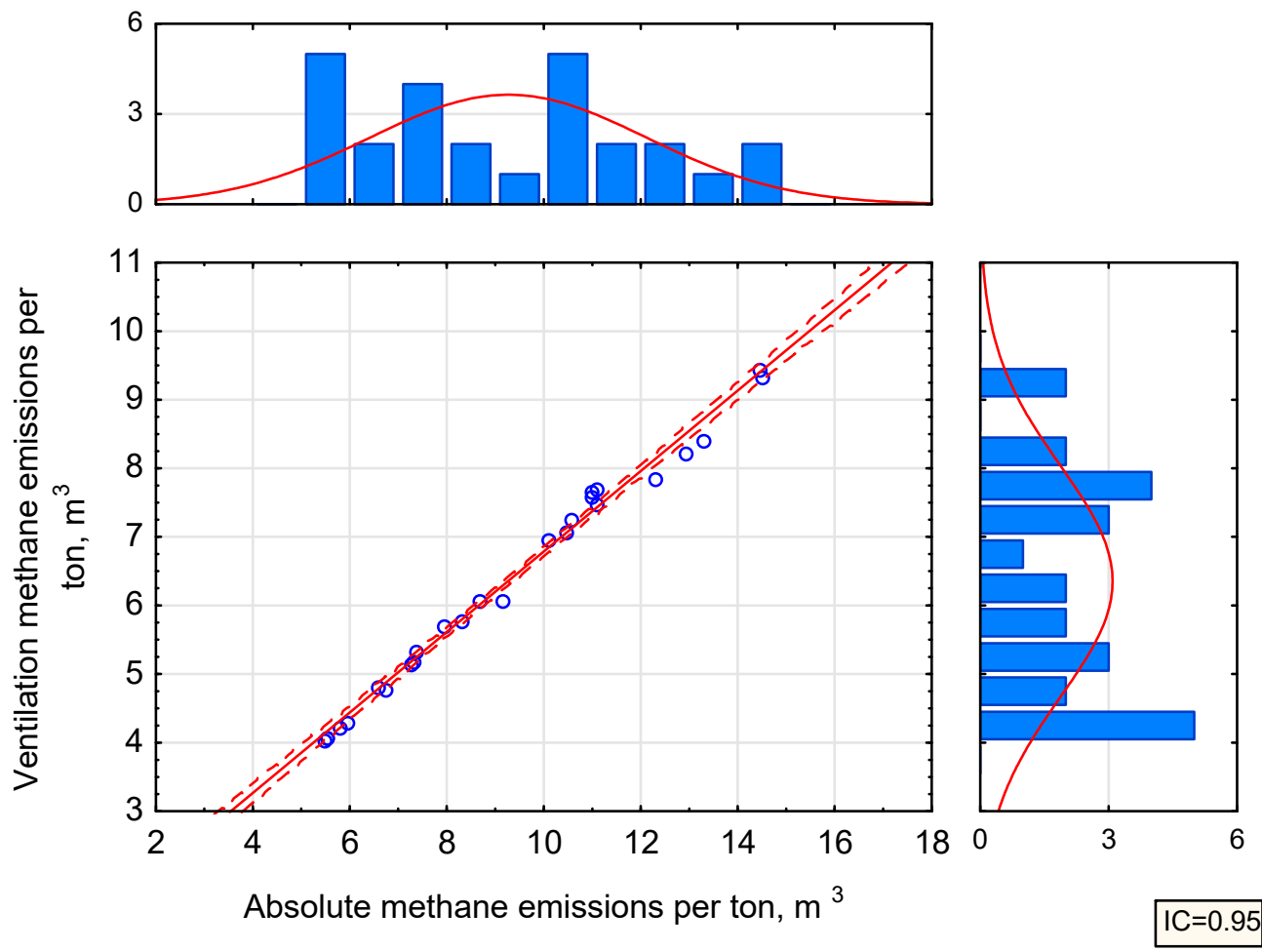

Figure 9. Relationship between absolute methane emissions and ventilation methane emissions per one ton in hard coal mines in Poland.
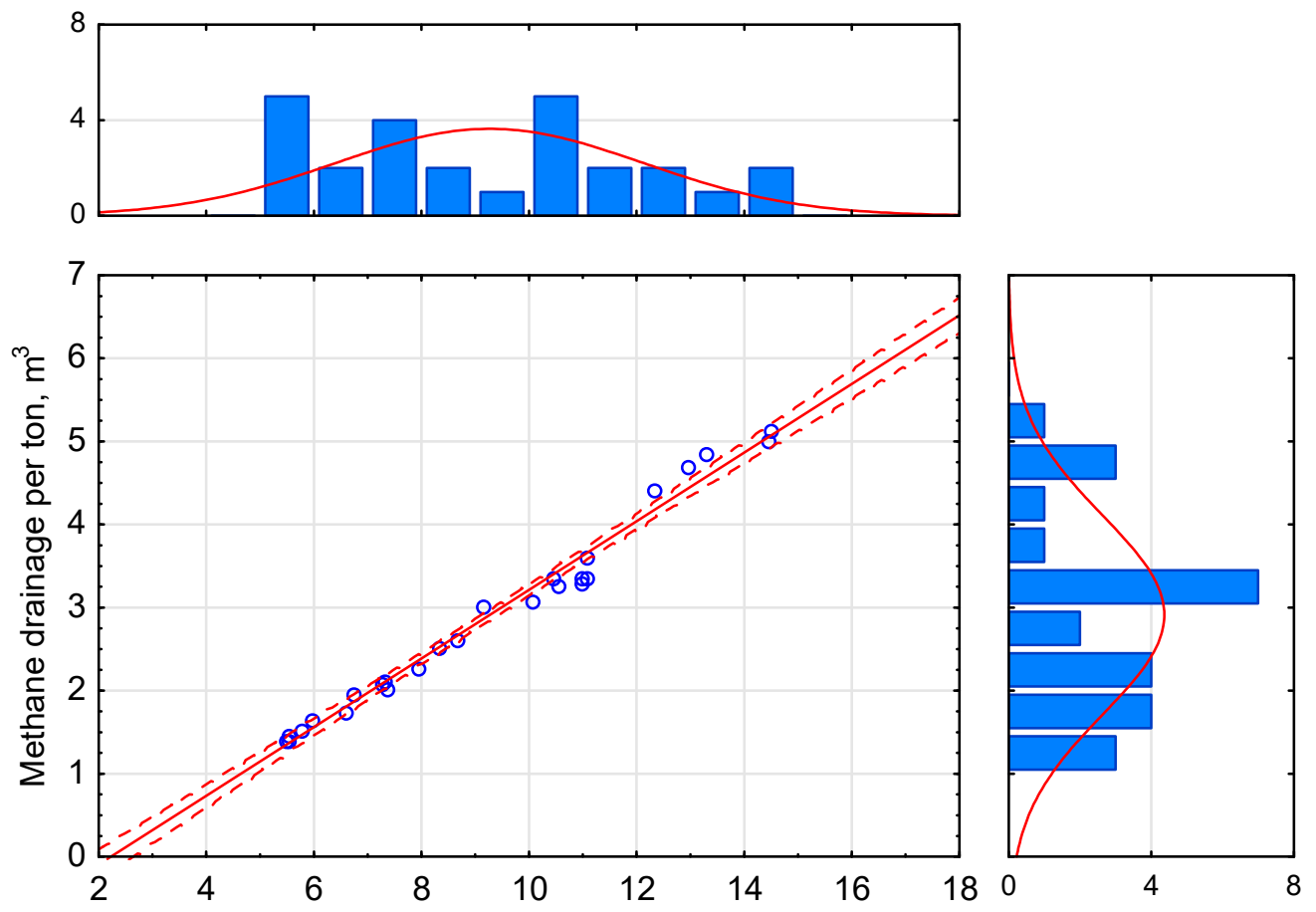

Absolute methane emissions per ton, $\mathrm{m}^{3}$

Figure 10. Relationship between absolute methane emissions and methane drainage per one ton in hard coal mines in Poland. 

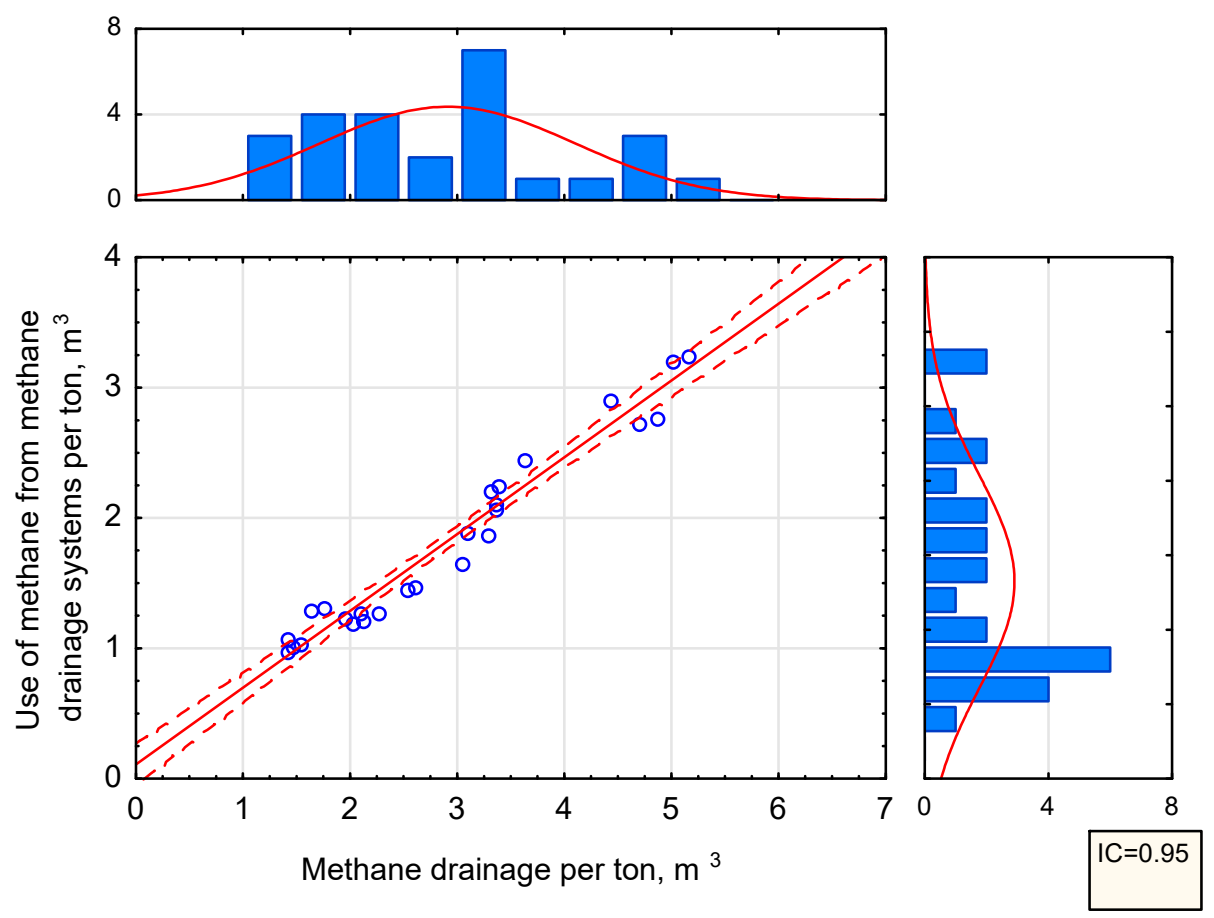

Figure 11. Relationship between methane drainage and uses of methane from methane drainage system per one ton in Poland.

Based on the statistical analysis, a strong positive correlation can be observed in most cases. A negative correlation can be noted only in the relationship between coal output and the total methane emissions.

This negative correlation should not be interpreted in such a way that a decrease in coal output causes an increase in methane emissions. The increase in methane emissions with a simultaneous decrease in coal output is associated with the phenomenon of exploitation at increasingly greater depths in Poland, where coal seams are more saturated with methane. Therefore, despite the noticeable decrease in coal output, methane emissions are still on the rise.

\subsection{Methods}

The further stage of the analysis of methane emissions from Polish mines involved the main part of the work, i.e., forecast. It aimed at determining the amount of methane emissions from Polish mines into the atmosphere with ventilation air (ventilation methane emissions), the amount of methane captured by methane drainage systems, and the amount of methane emitted from methane drainage systems into the atmosphere. Artificial neural networks were used for this part.

The main purpose was to determine the absolute and the relative values (per ton of coal extracted) of ventilation methane emissions, methane drainage, and the amount of methane emissions from methane drainage systems into the atmosphere by 2025 .

Artificial neural networks are alternative calculation techniques that are used in many areas $[37,38]$ for the prediction $[39,40]$ and the classification of large data sets and their analysis (e.g., in the context of finding cause and effect relationships between data) [41], data matching (especially in the event of information overload), and optimization [42,43].

Artificial neural networks (ANNs) were developed for the first time by McCulloch and Pitts [44]. The definition of an ANN frequently recurs to parallelism with biological paradigms, its structure resembling the brain's architecture and the human learning procedures [45]. 
The structure of a simple artificial neural network consists of three layers of neurons, of which the first layer is the input layer, the second is the hidden layer (there can even be several of them), and the last is the output layer (Figure 12).

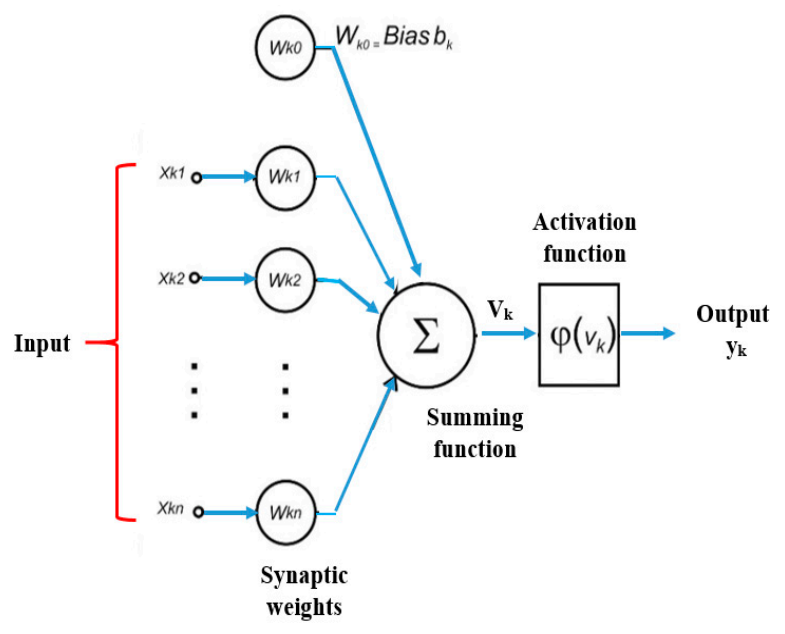

(a)

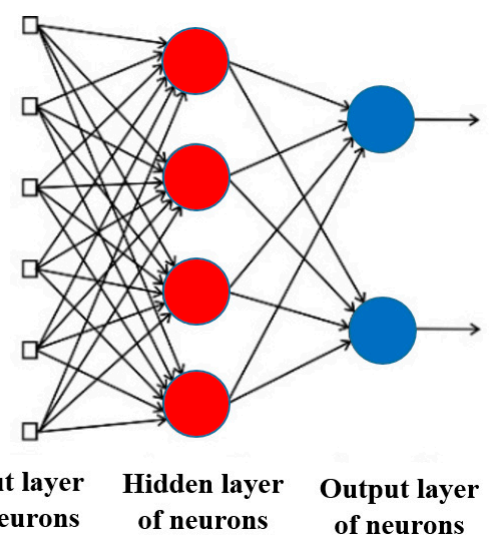

(b)

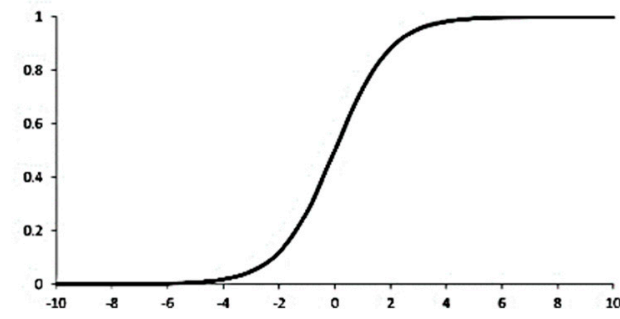

(c)

Figure 12. Schematic representation of an artificial neural network (ANN) architecture and basic operations (a), schematics of a three-layer neural network model layer (b), example of activation function (c) (own study based on [45]).

In order to predict both the absolute and the relative values (calculated per ton of extracted coal) of ventilation methane emissions, methane drainage, and the amount of methane emitted from methane drainage systems into the atmosphere by 2025, the multilayer perceptron (MLP) network was used. It was trained on real data.

In an MLP model, each $x_{j}$ variable from the input layer links with each neuron of the hidden layer through the connections with the weights $w_{i j}$. These values are then summed up, resulting in the $s_{i}$ signal:

$$
s_{i}=\sum_{j=1}^{N_{k-1}} w_{i j} \cdot x_{j}
$$

The differentiable activation function inside the hidden layer converts this signal and sends the result $y_{i}\left(y_{i}=f\left(s_{i}\right)\right)$ to the output layer. The number of neurons in the hidden layer is determined by a predefined approximation error, with the relationship between the number of neurons in the hidden layer and the approximation accuracy being directly proportionate. The weights of a given model are modified by means of an optimization algorithm, and the process is referred to as network learning. Since the error backpropagation algorithm uses the steepest descent method, this algorithm requires a large number of iterations, which may affect the speed of calculations [24,46-49]. 


\section{Results and Discussion}

Data sets presented in Tables 1 and 2, characterizing coal output, methane emission volume, methane drainage, and methane utilization. They were divided into two subsets (due to the limited size of the data set): the training data set ( $80 \%$ of cases) and the test data set ( $20 \%$ of cases).

In order to predict absolute and relative values by 2025 , networks consisting of a single hidden layer were used. The process of testing this network was carried out for the minimum number of neurons in the hidden layer, which was three.

Table 5 summarizes the structures of neural networks that obtained the highest correlation coefficients between actual and predicted quantities in the conducted training tests. During the optimization process of neural network parameters used for forecasting, various architectures were created, changing the number of neurons and studying various activation functions used in these networks. The network architectures presented in the paper turned out to be most advantageous (the highest values of the correlation coefficient) for individual studied variants.

Table 5. List of neural network structures used for the study.

\begin{tabular}{|c|c|c|c|c|c|}
\hline \multirow{2}{*}{ Forecast Variant } & \multirow{2}{*}{$\begin{array}{l}\text { Network } \\
\text { Structure }\end{array}$} & \multirow{2}{*}{$\begin{array}{l}\text { Correlation } \\
\text { Coefficient }\end{array}$} & \multirow{2}{*}{$\begin{array}{l}\text { Matching } \\
\text { Error }\end{array}$} & \multicolumn{2}{|c|}{ Activation Function-Neurons } \\
\hline & & & & Hidden & Output \\
\hline Ventilation methane emissions & MLP 6-10-1 & 0.943 & 3.0417 & $\begin{array}{l}\text { hyperbolic } \\
\text { tangent }\end{array}$ & $\begin{array}{c}\text { hyperbolic } \\
\text { tangent }\end{array}$ \\
\hline Methane drainage & MLP 4-7-1 & 0.790 & 10.88 & exponential & exponential \\
\hline $\begin{array}{l}\text { Methane emissions from methane } \\
\text { drainage systems }\end{array}$ & MLP 10-10-1 & 0.724 & 0.419 & exponential & logistic \\
\hline $\begin{array}{l}\text { Ventilation methane emissions } \\
\text { per ton }\end{array}$ & MLP 4-15-1 & 0.721 & 0.0135 & logistic & logistic \\
\hline Methane drainage per ton & MLP 4-5-1 & 0.799 & 0.0002 & $\begin{array}{l}\text { hyperbolic } \\
\text { tangent }\end{array}$ & linear \\
\hline $\begin{array}{l}\text { Methane emissions from methane } \\
\text { drainage systems per ton }\end{array}$ & MLP 8-34-1 & 0.676 & 0.0062 & linear & exponential \\
\hline
\end{tabular}

MLP = multilayer perceptron network.

As can be seen, for each of the studied parameters, networks with different structures obtained the best correlation coefficients.

The presented correlation coefficients for the training data set were at a satisfactory level, especially when taking into account the number of data adopted for the forecast ( 25 values determining the studied variables). Neural networks have special properties. This means that the more data there are, the better the network quality is and the more accurate the forecast will be. The lack of data on the amount of methane emitted by Polish hard coal mines before 1993 prevented the analysis of a larger data set.

The tests allowed the selection of neural networks (structure) that were used to carry out prognostic studies.

Based on the analyses, the predicted absolute and relative values were calculated (per ton of extracted coal) with regard to ventilation methane emissions, the amount of methane drainage, and the amount of methane emitted from methane drainage systems into the atmosphere by 2025 . The time horizon of the forecast (ex-ante) covered the years 2019-2025.

Figures 13-18 present the actual and the calculated (by the neural network) absolute and relative values of ventilation methane emissions, the amount of methane drainage, and the amount of methane emitted from methane drainage systems into the atmosphere. 


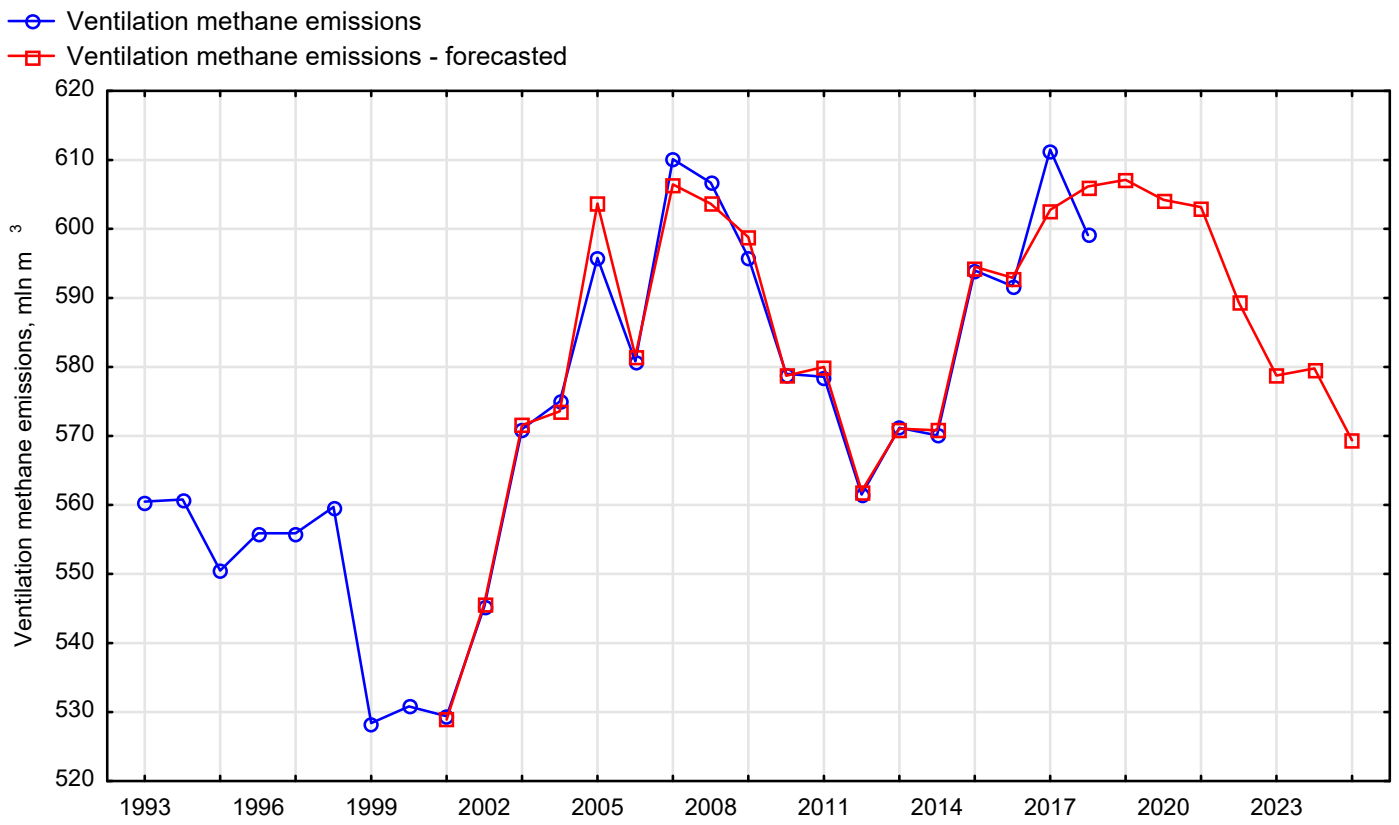

Figure 13. Actual and predicted amount of ventilation methane emissions into the atmosphere.

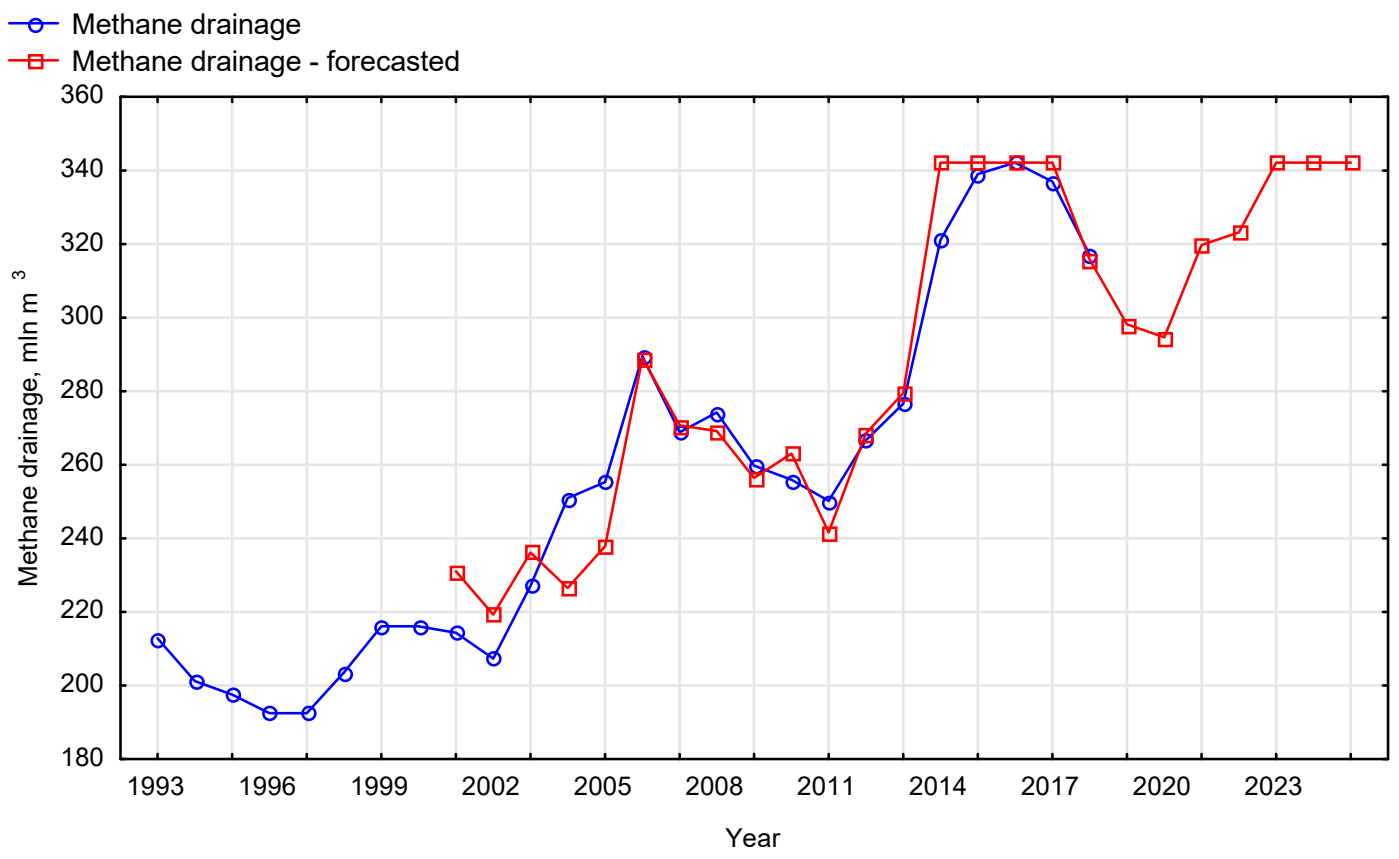

Figure 14. Actual and predicted amount of methane drainage. 


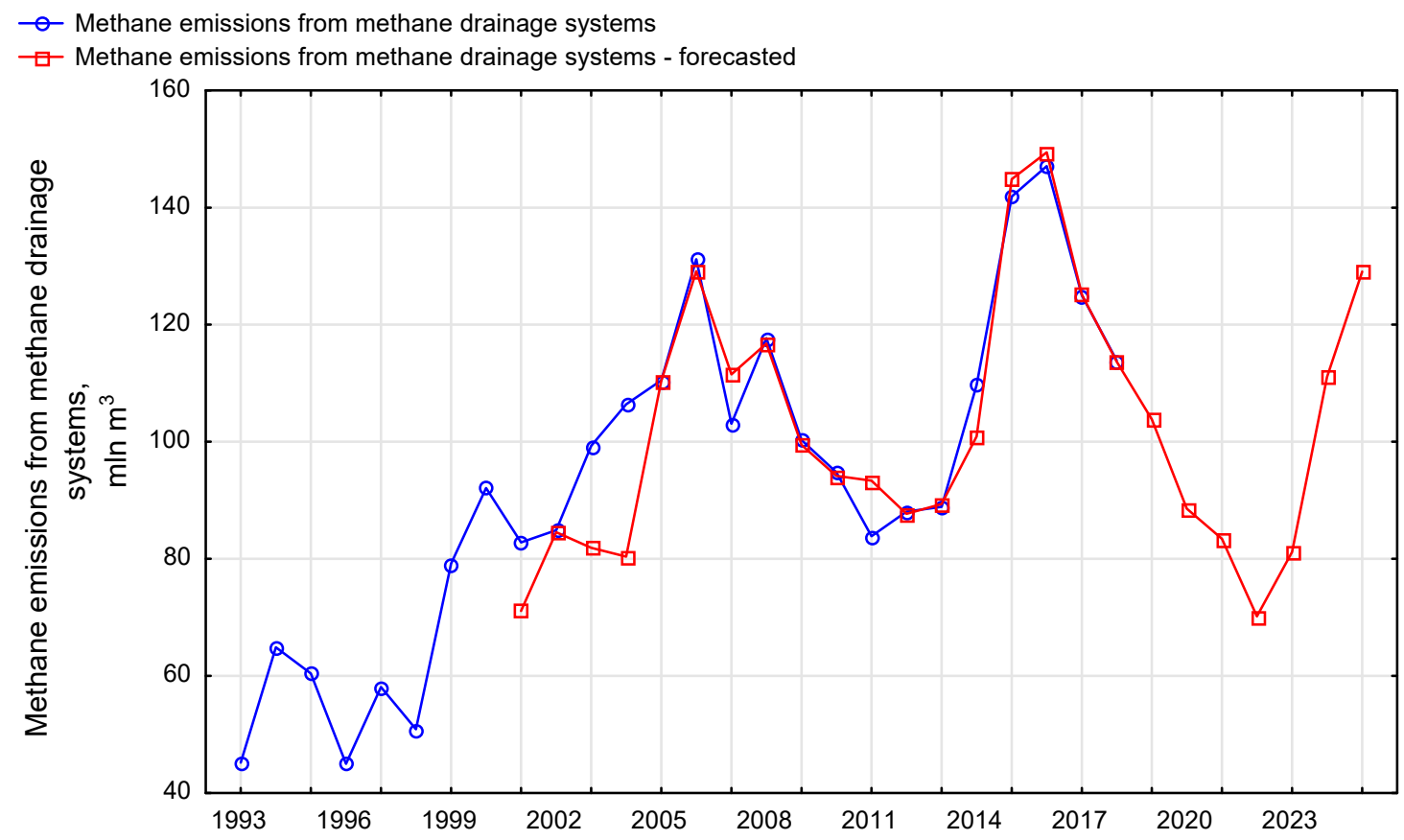

Figure 15. Actual and predicted amount of methane emissions from methane drainage systems into the atmosphere.

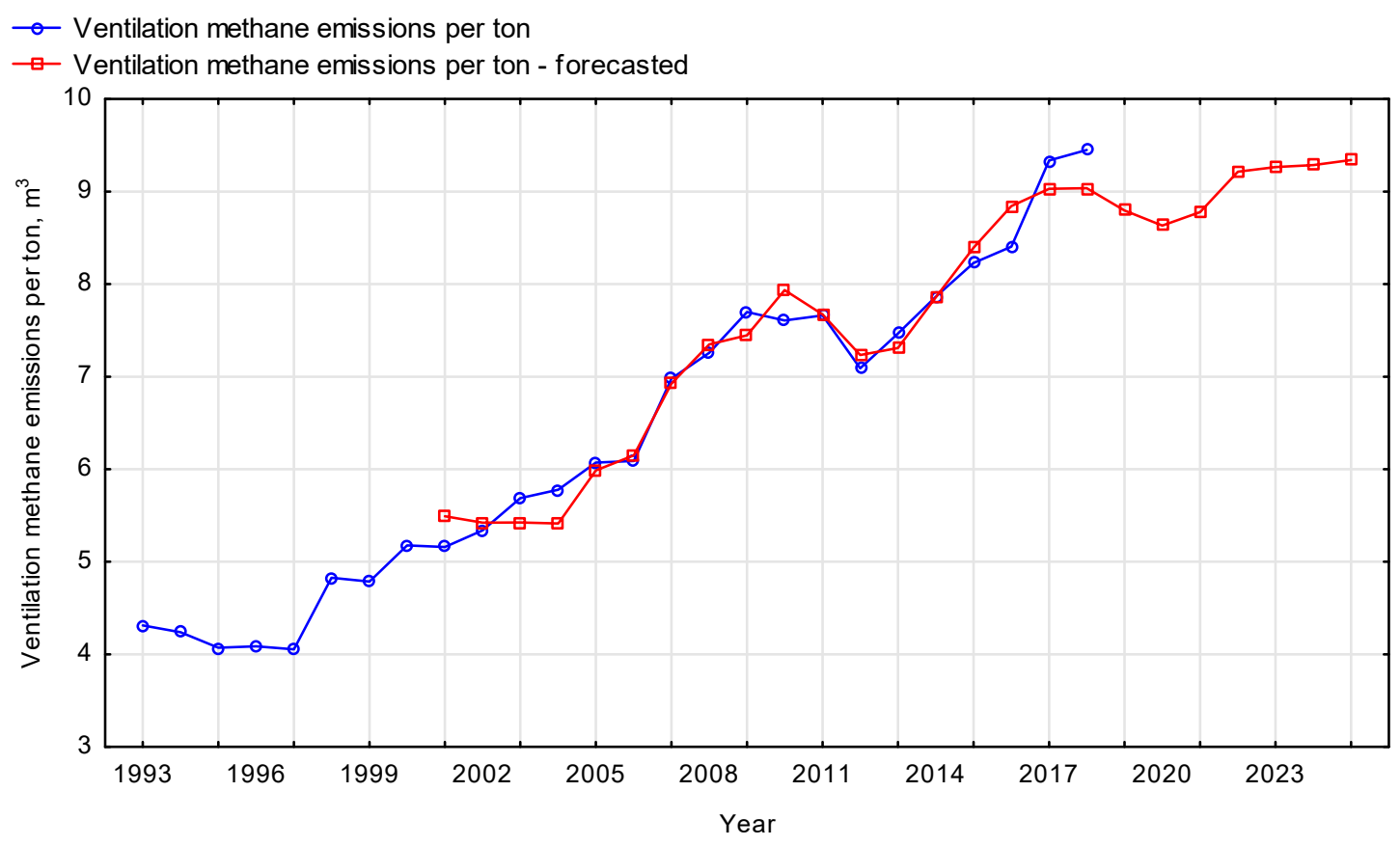

Figure 16. Actual and predicted amount of ventilation methane emissions into the atmosphere per ton of extracted coal. 


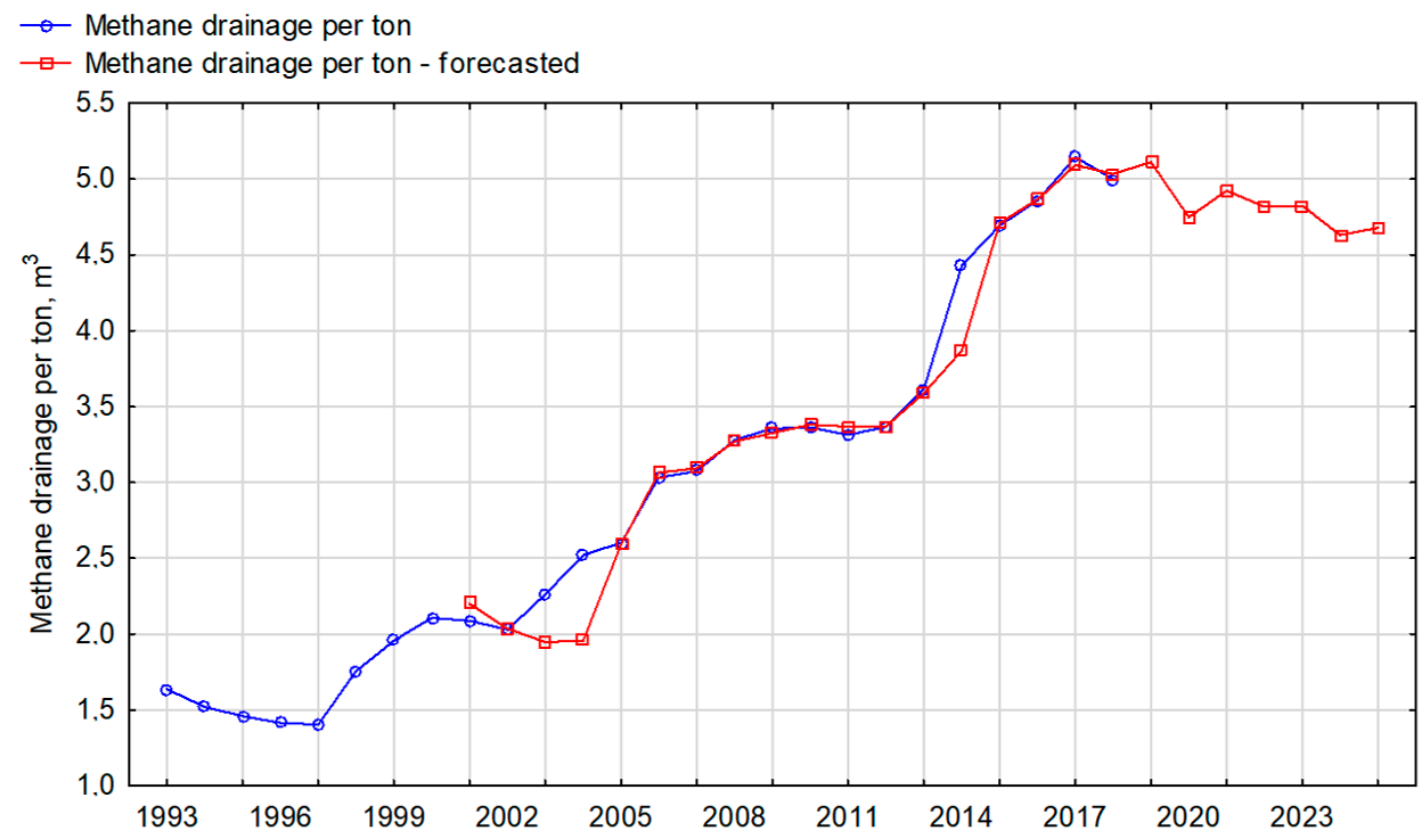

Figure 17. Actual and predicted amount of methane drainage per ton of extracted coal.

- Methane emissions from methane drainage systems

$\square$ Methane emissions from methane drainage systems - forecasted

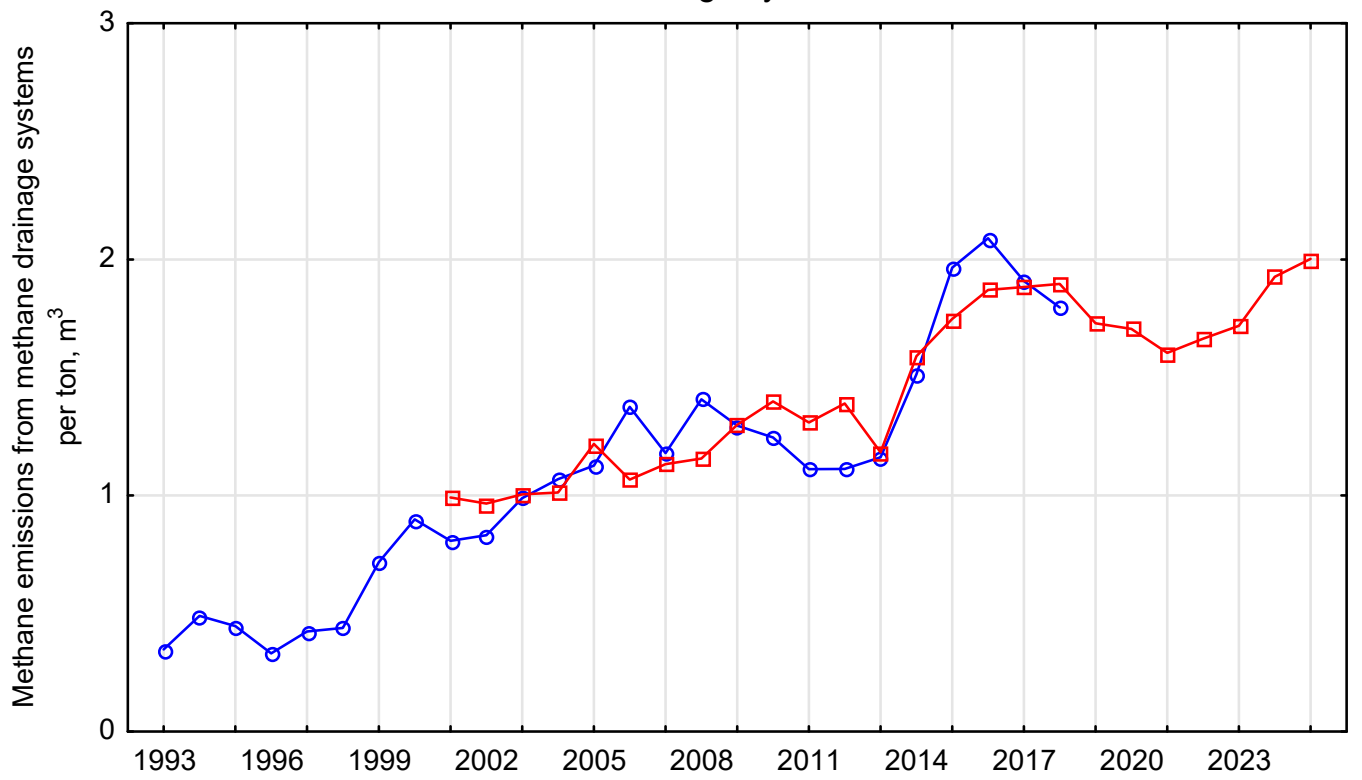

Figure 18. Actual and predicted amount of methane emissions from methane drainage systems into the atmosphere per ton of extracted coal.

The findings show that the actual course of methane ventilation emissions was most accurately mapped (Figure 13). The actual amount of methane drainage (Figure 14) and the amount of methane emissions from methane drainage systems into the atmosphere were slightly less accurately mapped (Figure 15).

As mentioned earlier, the amount of data used for the analysis had a significant impact on the results. Since the number of records used for the forecast was small and amounted to only 25 , the ex-post forecast was made only from 2001. 
Based on the results, it can also be stated that the predicted values of ventilation methane emissions, methane drainage, and methane emissions from methane drainage systems into the atmosphere were most often overstated for the lowest actual values and understated for the highest actual values. This was due to the approximation system based on which neural network models work.

In general, however, it can be said that the adopted architecture of the MLP network allowed the authors to accurately predict methane emissions into the atmosphere and methane drainage in the adopted time horizon. It seems reasonable to conduct further research to determine whether and how much the change in the forecast horizon will affect the accuracy of the calculations.

It is clear that, in the following years, a reduction in the amount of methane emitted into the environment should be expected (Figure 13), and by 2021, a decrease in methane emissions from methane drainage systems will have been reported. In this case, an increase in this value after 2021 is disconcerting (Figure 15). This slight predicted decrease in the amount of methane drainage in subsequent years is also not very optimistic (Figure 14). In this regard, decisive actions should be taken to improve the situation.

In order to reduce methane emissions into the environment, it is necessary to improve the efficiency of methane drainage systems. The amount of methane captured by these installations should be increased, and its emission into the environment from these systems should be reduced. It is unacceptable that the captured methane (as an energy raw material with very good properties) should again enter the atmosphere. The results indicate that methane drainage systems need to be modernized and their efficiency needs to be improved by ensuring methane collection from these systems. Failure to meet these conditions may lead to a significant increase in methane emissions into the atmosphere after 2021.

On the other hand, the analysis of forecast results in the scope of studied quantities related to one ton of coal are not very optimistic either. In terms of methane emissions into the environment, these values will be slightly increasing (Figure 16). The forecast regarding the amount of methane drainage per ton of extracted coal is also unsatisfactory, which shows only a slight decrease (Figure 17).

The graphic dispersions of the actual and the predicted values of studied parameters are shown in Figures 19 and 20.

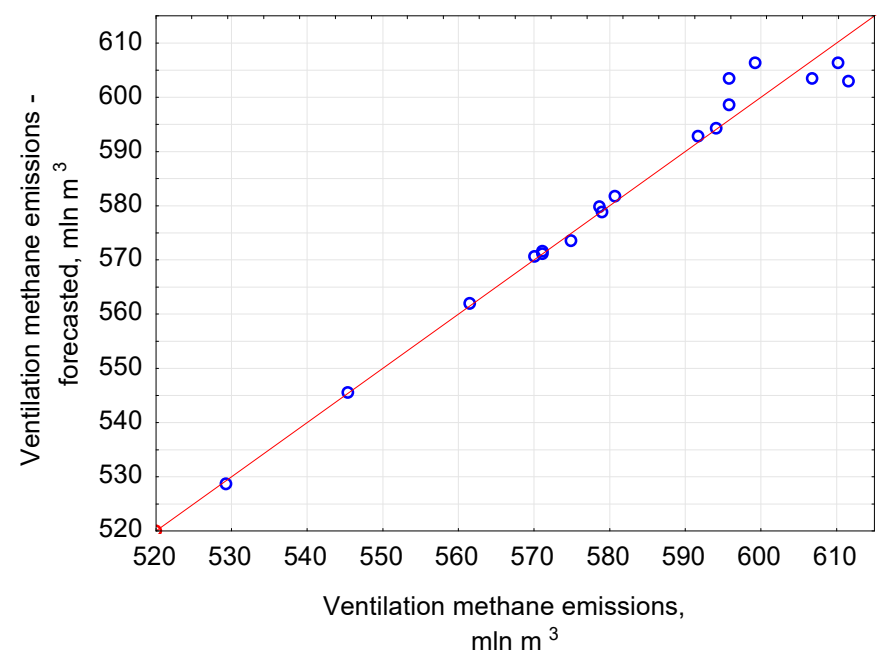

(a)

Figure 19. Cont. 


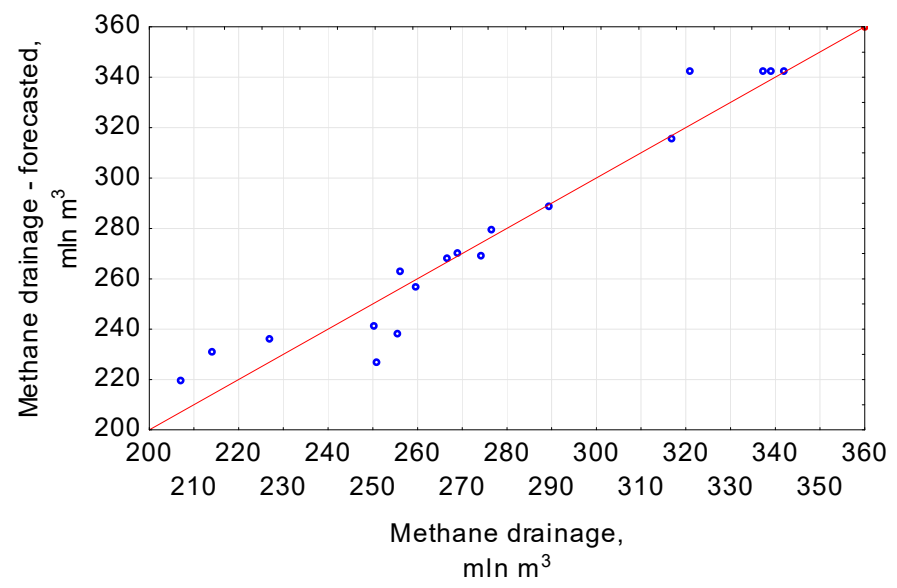

(b)

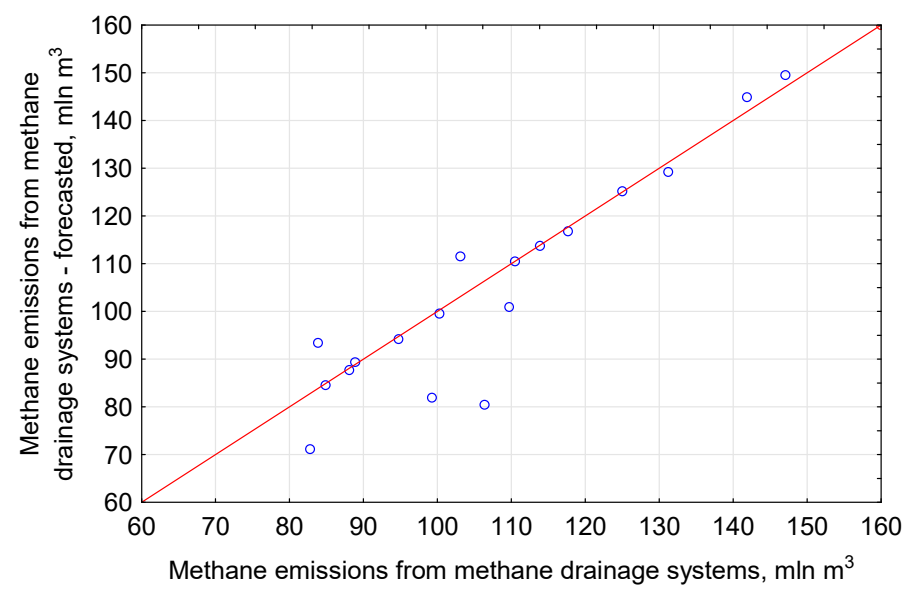

(c)

Figure 19. Predicted versus actual values of ventilation methane emissions into the atmosphere (-), methane drainage (b), and methane emissions from methane drainage systems into the atmosphere (c).

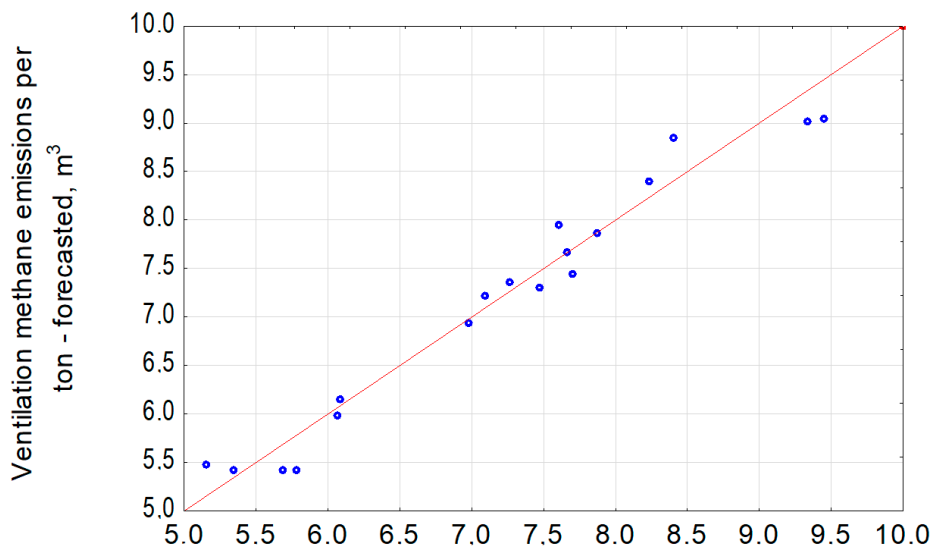

(a)

Figure 20. Cont. 


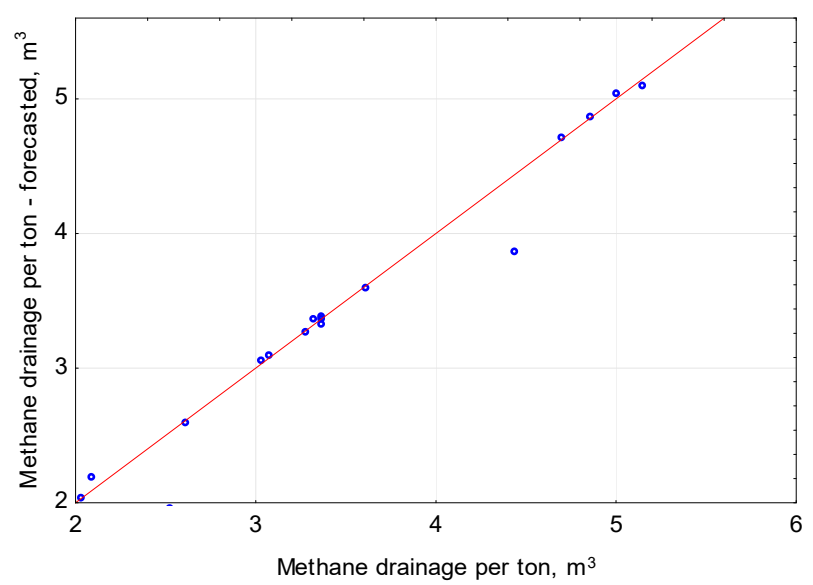

(b)

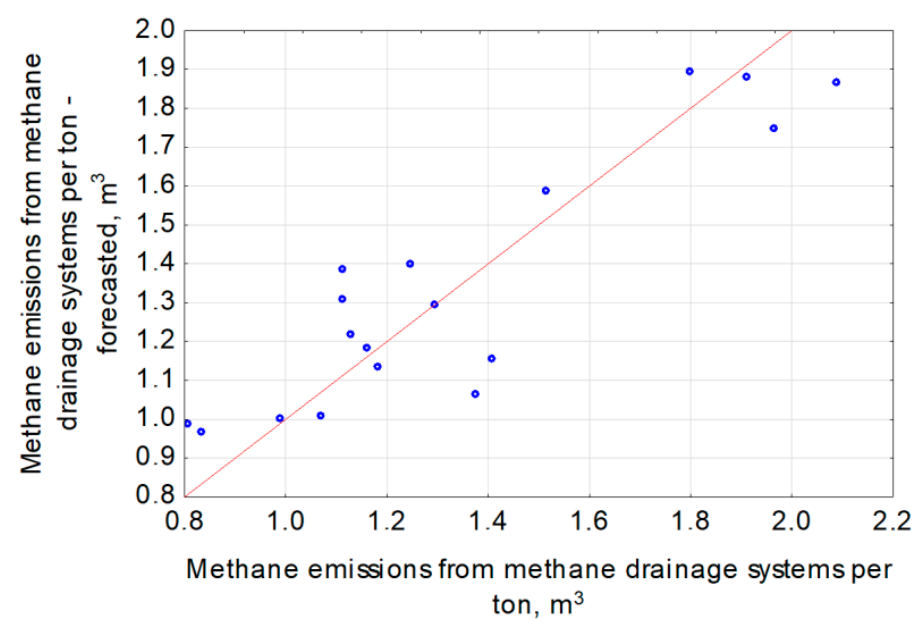

(c)

Figure 20. Predicted versus actual values of ventilation methane emissions into the atmosphere (a), methane drainage (b), and methane emissions from methane drainage systems into the atmosphere (c) in relation to one ton of extracted coal.

When analyzing the data presented in Figures 20 and 21, it can be seen that the results for methane emissions from methane drainage systems into the atmosphere per one ton of extracted coal showed the greatest dispersion. For this forecast, the amount of methane emissions showed the least accuracy. Unfortunately, despite the attempts to search for networks with different configurations, no better results were obtained for this case.

In order to better visualize the results, Figures 21 and 22 present histograms of the actual and the predicted values of studied parameters together with marked density functions. 


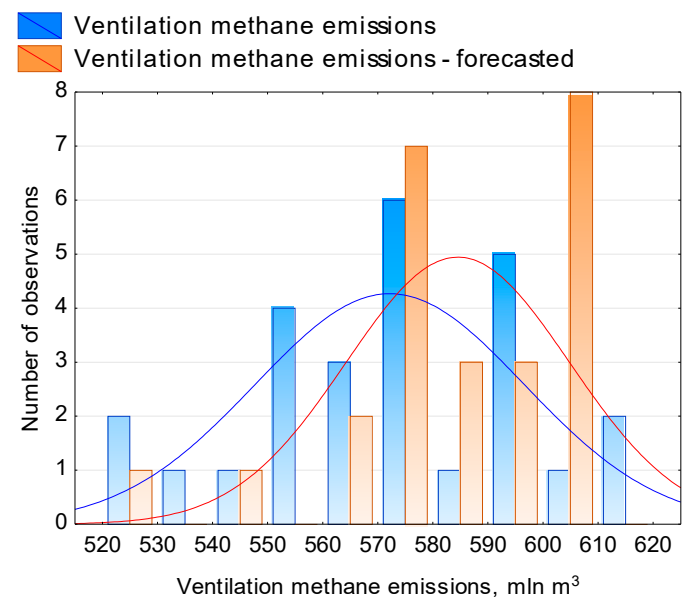

(a)

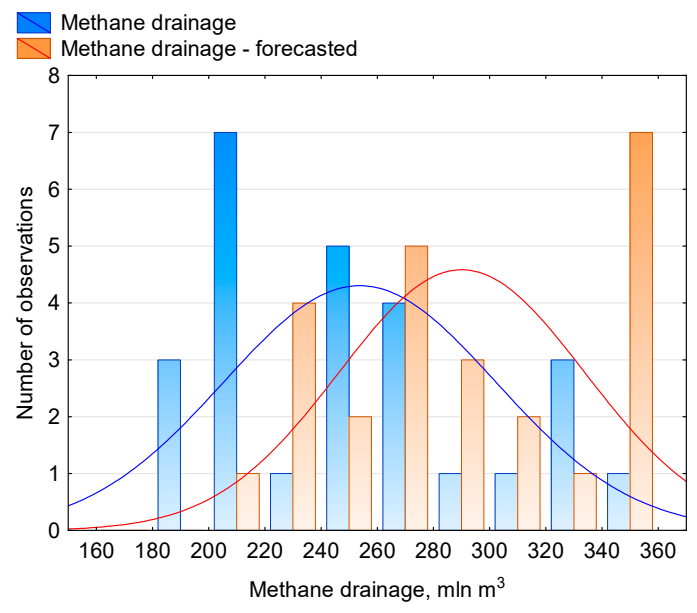

(b)

Methane emissions from methane drainage systems Methane emissions from methane drainage sy stems - forecasted

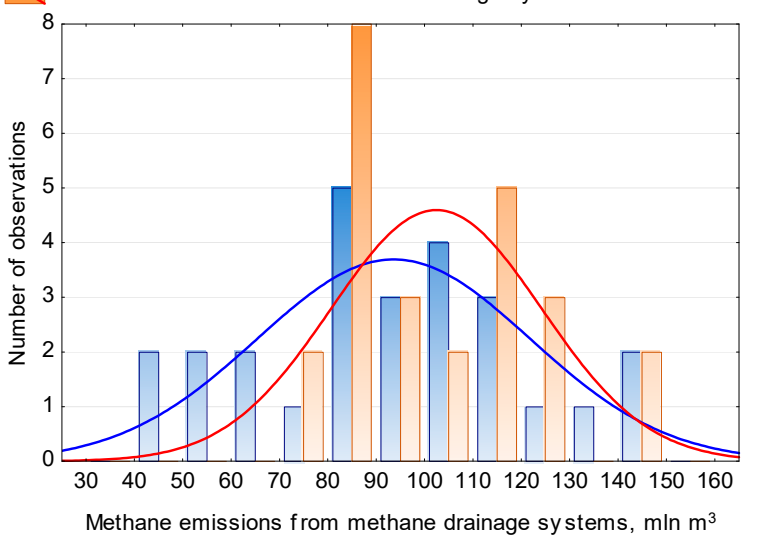

(c)

Figure 21. Histograms of the actual and the predicted values of ventilation methane emissions into the atmosphere (a), the amount of methane drainage (b), and methane emissions from methane drainage systems into the atmosphere (c).

Ventilation methane emissions per ton

Ventilation methane emissions per ton - forecasted

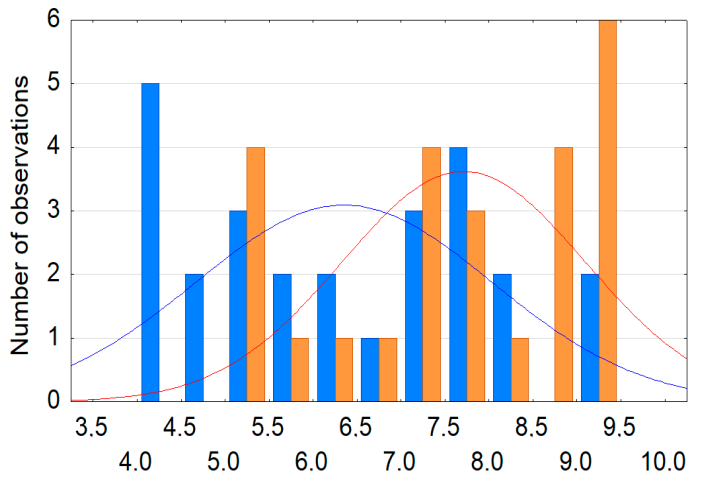

Ventilation methane emissions per ton, $\mathrm{m}^{3}$

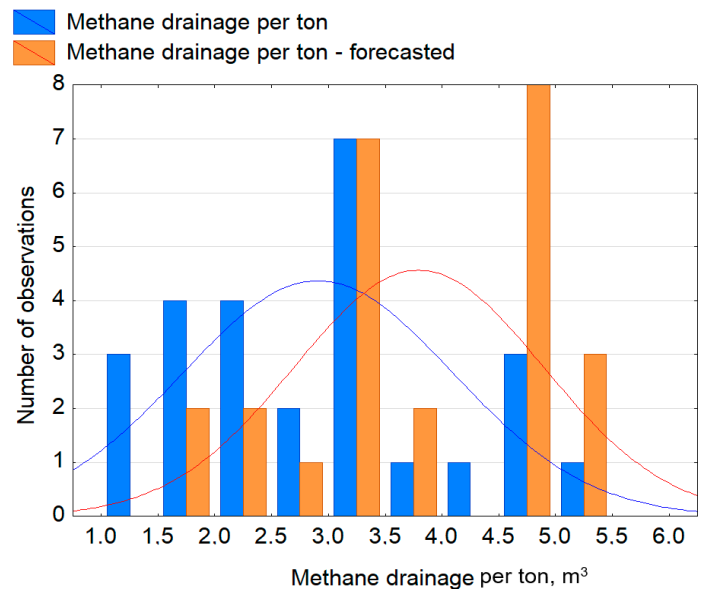

(b)

Figure 22. Cont. 


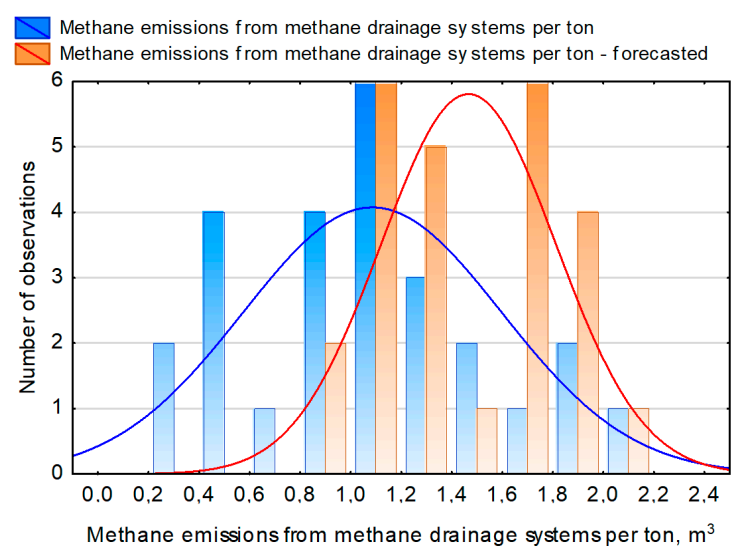

(c)

Figure 22. Histograms of the actual and the predicted values of ventilation methane emissions into the atmosphere (a), the amount of methane drainage (b), and methane emissions from methane drainage systems into the atmosphere (c) in relation to one ton of extracted coal.

Based on the results, it can be observed that, in many cases, we were dealing with the asymmetrical course of both the actual and the predicted values of studied parameters. Also, the determined density functions of real and predicted distributions showed certain differences, which was confirmed by the reported dispersion. Based on the histograms, the distribution of the values of studied parameters could be determined depending on the number of observations (in this case, the number of years in which these values occurred). It can also be seen that, when including the predicted values of studied parameters in these distributions, the range of these values was only slightly broadened. The predicted values most often coincided with the values reported in the studied years. However, they tended to concentrate more within the area of higher values of studied parameters (which was reflected in the shift in the density function of these distributions).

In addition, an error analysis was made between the actual values of studied parameters and their values obtained from the neural networks. The final error values for the studied parameters are summarized in Table 6.

Table 6. Summary of errors.

\begin{tabular}{cccccc}
\hline Forecast Variant & MAE & MAPE, \% & RMSE, \% & RMSE Ex-ante & RMSE Ex-post \\
\hline Ventilation methane emissions & 2.318 & 0.388 & 3.551 & 0.602 & 0.610 \\
\hline Methane drainage & 7.843 & 3.079 & 10.698 & 3.130 & 3.872 \\
\hline $\begin{array}{c}\text { Methane emissions from methane } \\
\text { drainage systems }\end{array}$ & 5.171 & 5.152 & 8.737 & 9.163 & 8.346 \\
\hline $\begin{array}{c}\text { Ventilation methane emissions } \\
\text { per ton }\end{array}$ & 0.198 & 2.789 & 0241 & 2.662 & 3.362 \\
\hline $\begin{array}{c}\text { Methane drainage per ton } \\
\begin{array}{c}\text { Methane emissions from methane } \\
\text { drainage systems per ton }\end{array}\end{array}$ & 0.104 & 3.494 & 0.205 & 4.244 & 6.059 \\
\hline
\end{tabular}

$\mathrm{MAE}=$ mean absolute error; $\mathrm{MAPE}=$ mean absolute percentage error; RMSE $=$ root mean square error.

When examining the prediction errors determined in terms of absolute and relative values of ventilation methane emissions, methane drainage, and methane emissions from methane drainage systems into the atmosphere, they were found to be at an acceptable level. 
The highest mean absolute percentage error (MAPE) error value was $9.9 \%$ for methane emissions from methane drainage systems into the atmosphere per one ton of extracted coal. The lowest MAPE error value was $3.8 \%$ for ventilation methane emissions.

In the case of root mean square error (RMSE) errors, the highest values were observed for the amount of methane drainage and the ventilation methane emissions from methane drainage systems.

It can therefore be claimed that, despite a relatively small amount of data, the results are satisfactory and allow the inference process to be carried out as to the direction of actions that can and should be taken in the future to reduce methane emissions into the natural environment and increase its economic use.

Based on the results, the proposed forecast, as with all kinds of forecasts, is subject to some uncertainty/inaccuracy. These inaccuracies also occur when predicting emissions of other greenhouse gases, e.g., carbon dioxide [50] or greenhouse gases in total [51]. Also, they result from the quality of input data and the tools used for analysis. However, more and more advanced systems for registering ventilation parameters are used, which means that these inaccuracies, especially in terms of input data, are becoming smaller. However, in the context of methane emission forecasting methods used thus far, the use of artificial neural networks seems fully justified, as the results obtained are most accurate.

In the previous publications $[29,52,53]$, methane emissions into mining excavations were specified, but no forecasts of atmospheric emissions or methane drainage were included.

In a study by [53], a method to estimate methane emissions from hard coal mines in Poland is presented. This method is based on the algorithm shown in [53] and involves the assumption that the methane emission index (EF) is calculated on the basis of coal output from methane mines and its total methane content. A similar subject is discussed by [29]. All these studies concern the estimation of methane emissions taking into account "a priori" the volume of extraction in a given year.

In this context, the use of neural networks gives much greater opportunities to forecast methane emissions, taking into account a larger number of factors affecting this emission.

From the mining point of view, it seems reasonable to use the developed method to forecast methane and other gas or substance emissions (e.g., harmful dust) not only for the entire industry but also for individual mines. This approach would allow the development of emission reduction programs dedicated to specific enterprises.

The method presented in this article is universal and, based on real data, also allows for methane emission forecasts from both coal mines and other economic sectors, taking into consideration factors that affect the volume of this emission.

\section{Conclusions}

This paper presents the method for predicting the state of methane emissions from underground coal mines. Both artificial neural networks and selected elements of statistical analysis were used for this study. Their role was to process data on methane emissions in recent years to later obtain as much information and knowledge as possible with regard to the direction of changes in methane emissions from mining operations in recent years and to determine their forecast for the next few years.

The study utilized data on coal output, ventilation methane emissions, and the amount of methane emitted from the methane drainage system into the environment. The amount of emissions with regard to these factors reported in the past helps forecast the amount of methane emissions into the atmosphere and the amount of methane drainage for the future. However, the presented forecasting method fails to take into account changes in market dynamics, operational practices, government oversight/regulations, or mitigation technologies, which may affect the amount of methane emissions.

Based on the results, it can be stated that the adopted MLP neural network architectures allow the forecast of methane emissions into the atmosphere and the amount of methane drainage in the adopted time horizon with satisfactory accuracy. At the same time, forecast errors in the absolute and the relative values of methane ventilation emissions, the methane drainage amounts, and the methane 
emissions from methane drainage systems into the atmosphere were at an acceptable level. It can therefore be concluded that, despite the relatively small amount of data, the findings are satisfactory.

The forecast results indicate that the amount of methane emitted into the environment will decrease in subsequent years; however, the pace of these changes seems to be too slow.

Thus, it appears reasonable to increase the intensity of methane capture from both mining excavations and coal seams. From a technical point of view, this course of action is most justified. However, the amount of methane captured in the methane drainage process needs to be significantly reduced, as such situations should not occur in this process. Ultimately, methane emissions from methane drainage systems need to strive for zero.

A serious problem was reported in terms of safety and the chance for economic extraction of large amounts of methane. It is related to increasing methane emissions per ton of extracted coal. Deteriorating coal mining conditions increase the amount of this gas in the exploited seams. This was also confirmed by the distribution of gas emissions shown on the histograms. This information should be used to take measures to decrease methane emissions into the environment and increase its usage.

The following approach to solving the problem of methane emissions during the mining production process should ideally fit into the implementation of the concept of sustainable development economy. Further development of the mining industry in the era of European decarbonization must also take greater account of both social and ecological aspects. In the case of methane, this seems to be achievable because this gas is very attractive in terms of energy and ecology (clean fuel).

It is therefore indisputable that methane, as a high-energy gas, should not be emitted into the atmosphere but used for economic purposes. Therefore, it is necessary to increase the efficiency of methane capture by methane drainage installations and to use it for electricity and heat production. This energy can be used by the mines themselves, and its surpluses can be an additional source of income.

One of the aims of the presented work was to show how small amounts of methane are currently being used in the energy sector. However, it is completely incomprehensible to emit methane captured by methane drainage systems into the atmosphere. In this respect, it is necessary for the mining enterprises to take decisive actions, as there are technologies that allow the economic use of methane, such as cogeneration and trigeneration systems.

To sum up, the developed method and the obtained results can effectively support decisions made to decrease methane emissions into the atmosphere and increase the amount of methane utilized.

The neural networks and the statistical methods used for the analysis enabled the acquisition of a substantial amount of important information and knowledge in the field of methane emissions in the mining production process.

The authors of this article hope that the practical application of the findings will improve the image of underground mining and create new areas for its development.

Author Contributions: Conceptualization, M.T. and J.B.; methodology, J.B. and M.T.; software, M.T.; validation, J.B. and M.T.; formal analysis, J.B. and M.T.; investigation, J.B. and M.T.; resources, J.B. and M.T.; data curation, J.B. and M.T.; writing of the original draft preparation, J.B. and M.T.; writing of review and editing, J.B. and M.T.; visualization, M.T.; supervision, J.B.; project administration, J.B.; funding acquisition, M.T. and J.B.

Funding: This research was funded by SUBB, grant numbers 06/030/BKM_18/0041 and 06/030/BKM_19/0048.

Conflicts of Interest: The authors declare no conflict of interest.

\section{References}

1. Crow, D.J.G.; Balcombe, P.; Brandon, N.; Hawkes, A.D. Assessing the impact of future greenhouse gas emissions from natural gas production. Sci. Total Environ. 2019, 668, 1242-1258. [CrossRef] [PubMed]

2. Institute of Environmental Protection-National Research Institute. National Inventory Report 2016. Report Made for the Purposes United Nations Framework Convention on Climate Change and the Kyoto Protocol. Available online: https://www.kobize.pl/uploads/materialy/materialy_do_pobrania/krajowa_ inwentaryzacja_emisji/NIR_2016_POL_Streszczenie_05.2016.pdf (accessed on 26 September 2019). 
3. Tong, R.; Yang, Y.; Ma, X.; Zhang, Y.; Li, S.; Yang, H. Risk Assessment of Miners' Unsafe Behaviors: A Case Study of Gas Explosion Accidents in Coal Mine, China. Int. J. Environ. Res. Public Health 2019, $16,1765$. [CrossRef] [PubMed]

4. Brodny, J.; Tutak, M. Analysis of Methane Emission into the Atmosphere as a Result of Mining Activity, 16th ed.; International Multidisciplinary Scientific GeoConference SGEM: Sofia, Bulgaria, 2016; Book 4; Volume 3, pp. 83-90. [CrossRef]

5. Zhou, H.; Yang, Q.; Cheng, Y.; Ge, C.; Chen, J. Methane drainage and utilization in coal mines with strong coal and gas outburst dangers: A case study in Luling mine, China. J. Nat. Gas Sci. Eng. 2014, 20, 357-365. [CrossRef]

6. Warmuzinski, K. Harnessing methane emissions from coal mining. Process Saf. Environ. Prot. 2008, 86, 315-320. [CrossRef]

7. Balcombe, P.; Speirs, J.F.; Brandon, N.P.; Hawkes, A.D. Methane emissions: Choosing the right climate metric and time horizon. Environ. Sci. Process. Impacts 2018, 20, 1323-1339. [CrossRef] [PubMed]

8. Climate Change 2013: The Physical Science Basis; Contribution of Working Group I to the Fifth Assessment Report of the Intergovernmental Panel on Climate Change; Cambridge University Press: Cambridge, UK; New York, NY, USA, 2013; p. 1535.

9. Karacan, C.O.; Ruiz, F.A.; Cotèc, M.; Phipps, S. Coal mine methane: A review of capture and utilization practices with benefits to mining safety and to greenhouse gas reduction. Int. J. Coal Geol. 2011, 86, 121-156. [CrossRef]

10. Kędzior, S. Accumulation of coalbed methane in the south-west part of the Upper Silesian Coal Basin (southern Poland). Int. J. C. Geol. 2009, 80, 20-34. [CrossRef]

11. Yang, X.; Liu, Y.; Li, Z.; Zhang, C.; Xing, Y. Vacuum Exhaust Process in Pilot-Scale Vacuum Pressure Swing Adsorption for Coal Mine Ventilation Air Methane Enrichment. Energies 2018, 11, 1030. [CrossRef]

12. Słoczyński, T.; Drozd, A. Coalbed methane (CBM)-Global experience and the prospects of development in Poland. Nafta Gaz Sci. Technol. Oil Gas Ind. 2017, 11, 851-856.

13. Cheng, Y.; Wang, L.; Zhang, X. Environmental impact of coal mine methane emissions and responding strategies in China. Int. J. Greenh. Gas Control 2011, 5, 157-166. [CrossRef]

14. EPA's Report on the Environment. Available online: https://cfpub.epa.gov/roe/documents/EPAROE_FINAL_ 2008.PDF (accessed on 2 September 2019).

15. Tucki, K.; Orynycz, O.; Świć, A.; Mitoraj-Wojtanek, M. The Development of Electromobility in Poland and EU States as a Tool for Management of $\mathrm{CO}_{2}$ Emissions. Energies 2019, 12, 2942. [CrossRef]

16. Xie, S.; Lin, S.; Zhang, Q.; Tian, Z.; Wang, Y. Selective electrocatalytic conversion of methane to fuels and chemicals. J. Energy Chem. 2018, 27, 1629-1636. [CrossRef]

17. WUG. Available online: http://www.wug.gov.pl/bhp/stan_bhp_w_gornictwie (accessed on 2 September 2019).

18. Krause, E.; Łukowicz, K. Dynamic Prediction of Absolute Methane Emissions on Longwalls; Technical Guide; GIG: Katowice, Poland, 2000.

19. Krause, E.; Smoliński, A. Analysis and Assessment of Parameters Shaping Methane Hazard in Longwall Areas. J. Sustain. Min. 2013, 12, 13-19. [CrossRef]

20. Wierzbowski, M.; Filipiak, I.; Lyzwa, W. Polish energy policy 2050-An instrument to develop a diversified and sustainable electricity generation mix in coal-based energy system. Renew. Sustain. Energy Rev. 2017, 74, 51-70. [CrossRef]

21. Mishra, D.P.; Kumar, P.; Panigrahi, D.C. Dispersion of methane in tailgate of a retreating longwall mine: A computational fluid dynamics study. Environ. Earth Sci. 2016, 75, 475. [CrossRef]

22. Tutak, M.; Brodny, J. Analysis of Influence of Goaf Sealing from Tailgate on the Methane Concentration at the Outlet from the Longwall. IOP Conf. Ser. Earth Environ. Sci. 2017, 95, 042025. [CrossRef]

23. Felka, D.; Brodny, J. Application of Neural-Fuzzy System in Prediction of Methane Hazard. In Proceedings of the International Conference on Intelligent Systems in Production Engineering and Maintenance, Wroclaw, Poland, 28-29 September 2017; Springer: Berlin/Heidelberg, Germany, 2017; pp. 151-160.

24. Tutak, M.; Brodny, J. Predicting Methane Concentration in Longwall Regions Using Artificial Neural Networks. Int. J. Environ. Res. Public Health 2019, 16, 1406. [CrossRef]

25. Liobikienè, G.; Butkus, M.; Matuzevičiūtè, K. The Contribution of Energy Taxes to Climate Change Policy in the European Union (EU). Resources 2019, 8, 63. [CrossRef] 
26. Tucki, K.; Orynycz, O.; Wasiak, A.; Świć, A.; Dybaś, W. Capacity Market Implementation in Poland: Analysis of a Survey on Consequences for the Electricity Market and for Energy Management. Energies 2019, 12, 839. [CrossRef]

27. Duda, A.; Krzemień, A. Forecast of methane emission from closed underground coal mines exploited by longwall mining-A case study of Anna coal mine. J. Sustain. Min. 2018, 17, 189-194. [CrossRef]

28. Krause, E.; Pokryszka, Z. Investigations on Methane Emission from Flooded Workings of Closed Coal Mines. J. Sustain. Min. 2013, 12, 40-45. [CrossRef]

29. Kirchgessner, A.D.; Piccot, S.D.; Winkler, J.D. Estimate of global methane emissions from coal mines. Chemosphere 1993, 26, 453-472. [CrossRef]

30. Sen, P.; Roy, M.; Pal, P. Application of ARIMA for forecasting energy consumption and GHG emission: A case study of an Indian pig iron manufacturing organization. Energy 2016, 116, 1031-1038. [CrossRef]

31. Lotfalipour, M.R.; Ali Falahi, M.; Bastam, M. Prediction of $\mathrm{CO}_{2}$ Emissions in Iran using Grey and ARIMA Models. Int. J. Energy Econ. Policy 2013, 3, 229-237.

32. Mohsen Hosseini, S.; Saifoddin, A.; Shirmohammadi, R.; Aslani, A. Forecasting of $\mathrm{CO}_{2}$ emissions in Iran based on time series and regression analysis. Energy Rep. 2019, 5, 619-631. [CrossRef]

33. Kędzior, S. Potencjał zasobowy metanu pokładów węgla w Polsce w kontekście uwarunkowań geologicznych. Gosp. Sur. Min. 2008, 24, 155-173.

34. Polish Geological Institute National Research Institute. Available online: https://www.pgi.gov.pl/psg-1/psg-2/ informacja-i-szkolenia/wiadomosci-surowcowe/10856-zasoby-metanu-z-pokladow-wegla-w-polsce.html (accessed on 2 September 2019).

35. Kędzior, S.; Dreger, M. Methane occurrence, emissions and hazards in the Upper Silesian Coal Basin, Poland. Int. J. Coal Geol. 2019, 211, 103226. [CrossRef]

36. Kabiesz, J. Annual Report on the State of Basic Natural and Technical Hazards in Hard Coal Mining; GIG: Katowice, Poland, 2018.

37. Sasiada, M.; Fraczek-Szczypta, A.; Tadeusiewicz, R. Efficiency testing of artificial neural networks in predicting the properties of carbon nanomaterials as potential systems for nervous tissue stimulation and regeneration. Bio-Algorithms Med-Syst. 2017, 13, 25-35. [CrossRef]

38. Papagera, A.; Ioannou, K.; Zaimes, G.; Iakovoglou, V.; Simeonidou, M. Simulation and prediction of water allocation using artificial neural networks and a spatially distributed hydrological model. Econ. Inform. 2014, $6,101-111$.

39. Ferreira, J.; Callou, G.; Josua, A.; Tutsch, D.; Maciel, P. An Artificial Neural Network Approach to Forecast the Environmental Impact of Data Centers. Information 2019, 10, 113. [CrossRef]

40. Lee, S.; Jung, S.; Lee, J. Prediction Model Based on an Artificial Neural Network for User-Based Building Energy Consumption in South Korea. Energies 2019, 12, 608. [CrossRef]

41. Bourobou, S.T.M.; Yoo, Y. User Activity Recognition in Smart Homes Using Pattern Clustering Applied to Temporal ANN Algorithm. Sensors 2015, 15, 11953-11971. [CrossRef] [PubMed]

42. Lee, H.-J.; Jhang, S.-S.; Yu, W.-K.; Oh, J.-H. Artificial Neural Network Control of Battery Energy Storage System to Damp-Out Inter-Area Oscillations in Power Systems. Energies 2019, 12, 3372. [CrossRef]

43. Kampelis, N.; Tsekeri, E.; Kolokotsa, D.; Kalaitzakis, K.; Isidori, D.; Cristalli, C. Development of Demand Response Energy Management Optimization at Building and District Levels Using Genetic Algorithm and Artificial Neural Network Modelling Power Predictions. Energies 2018, 11, 3012. [CrossRef]

44. McCulloch, W.S.; Pitts, W. A logical calculus of the ideas immanent in nervous activity. Bull. Math. Biophys. 1943, 5, 115-133. [CrossRef]

45. Barone, G.; Mazzoleni, P.; Spagnolo, G.V.; Raneri, S. Artificial neural network for the provenance study of archaeological ceramics using clay sediment database. J. Cult. Herit. 2019, 38, 147-157. [CrossRef]

46. Viotti, P.; Liuti, G.; Di Genova, P. Atmospheric urban pollution: Applications of an artificial neural network (ANN) to the city of Perugia. Ecol. Model. 2002, 148, 27-46. [CrossRef]

47. Werbos, P. Generalization of Backpropagation with application to a recurrent gas market model. Neural Netw. 1988, 1, 339-356. [CrossRef]

48. Leonard, J.; Kramer, M.A. Improvement of the backpropagation algorithm for training neural networks. Comput. Chem. Eng. 1990, 14, 337-341. [CrossRef]

49. Obuchowicz, A. Optimizing the architecture of neural networks. Biocybernetyka i inżynieria biomedyczna 2000, $6,323-367$. 
50. Hong, T.; Jeong, K.; Koo, K. An optimized gene expression programming model for forecasting the national $\mathrm{CO}_{2}$ emissions in 2030 using the metaheuristic algorithms. Appl. Energy 2018, 228, 808-820. [CrossRef]

51. Antanasijevića, D.Z.; Ristić, M.D.; Perić-Grujić, A.A.; Pocajt, V.V. Forecasting GHG emissions using an optimized artificial neural network model based on correlation and principal component analysis. Int. J. Greenh. Gas Control 2014, 20, 244-253. [CrossRef]

52. Intergovernmental Panel on Climate Change. Guidelines for National Greenhouse Gas Inventories; Institute for Global Environmental Strategies: Kanagawa, Japan, 2006; Volume 2.

53. Patyńska, R. The methane emission factor from the coal mines in Poland. Zeszyty Naukowe Instytutu Gospodarki Surowcami Mineralnymi i Energia Polskiej Akademii Nauk 2016, 94, 67-78.

(C) 2019 by the authors. Licensee MDPI, Basel, Switzerland. This article is an open access article distributed under the terms and conditions of the Creative Commons Attribution (CC BY) license (http://creativecommons.org/licenses/by/4.0/). 